\title{
GIRK Channel Activity in Dopamine Neurons of the Ventral Tegmental Area Bidirectionally Regulates Behavioral Sensitivity to Cocaine
}

\author{
№ra M. McCall, ${ }^{1}$-Ezequiel Marron Fernandez de Velasco, ${ }^{2}$ and $\odot$ Kevin Wickman ${ }^{2}$ \\ ${ }^{1}$ Graduate Program in Neuroscience, and ${ }^{2}$ Department of Pharmacology, University of Minnesota, Minneapolis, Minnesota 55455
}

\begin{abstract}
Dopamine (DA) neurons of the VTA have been widely implicated in the cellular and behavioral responses to drugs of abuse. Inhibitory $\mathrm{G}$ protein signaling mediated by $\mathrm{GABA}_{\mathrm{B}}$ receptors $\left(\mathrm{GABA}_{\mathrm{B}} \mathrm{Rs}\right)$ and $\mathrm{D}_{2} \mathrm{DA}$ receptors $\left(\mathrm{D}_{2} \mathrm{Rs}\right)$ regulates the excitability of VTA DA neurons, $\mathrm{DA}$ neurotransmission, and behaviors modulated by $D A$. Most of the somatodendritic inhibitory effect of $G_{A B A} A_{B} R$ and $D_{2} R$ activation on DA neurons reflects the activation of $\mathrm{G}$ protein-gated inwardly rectifying $\mathrm{K}^{+}$(GIRK) channels. Furthermore, GIRK-dependent signaling in VTA DA neurons can be weakened by exposure to psychostimulants and strengthened by phasic DA neuron firing. The objective of this study was to determine how the strength of GIRK channel activity in VTA DA neurons influences sensitivity to cocaine. We used a Cre-dependent viral strategy to overexpress the individual GIRK channel subunits in VTA DA neurons of male and female adult mice, leading to enhancement (GIRK2) or suppression (GIRK3) of GIRK channel activity. Overexpression of GIRK3 decreased somatodendritic $\mathrm{GABA}_{\mathrm{B}} \mathrm{R}$ - and $\mathrm{D}_{2} \mathrm{R}$-dependent signaling and increased cocaine-induced locomotor activity, whereas overexpression of GIRK2 increased $\mathrm{GABA}_{\mathrm{B}} \mathrm{R}$-dependent signaling and decreased cocaine-induced locomotion. Neither manipulation impacted anxiety- or depressionrelated behavior, despite the link between such behaviors and DA signaling. Together, these data show that behavioral sensitivity to cocaine in mice is inversely proportional to the strength of GIRK channel activity in VTA DA neurons and suggest that direct activators of the unique VTA DA neuron GIRK channel subtype (GIRK2/GIRK3 heteromer) could represent a promising therapeutic target for treatment of addiction.
\end{abstract}

Key words: D2 dopamine receptor; dopamine; G protein; $\mathrm{GABA}_{\mathrm{B}}$; Kir3; VTA

Significance Statement

Inhibitory $\mathrm{G}$ protein signaling in dopamine (DA) neurons, including that mediated by $\mathrm{G}$ protein-gated inwardly rectifying $\mathrm{K}^{+}$ (GIRK) channels, has been implicated in behavioral sensitivity to cocaine. Here, we used a viral approach to bidirectionally manipulate GIRK channel activity in DA neurons of the VTA. We found that decreasing GIRK channel activity in VTA DA neurons increased behavioral sensitivity to cocaine, whereas increasing GIRK channel activity decreased behavioral sensitivity to cocaine. These manipulations did not alter anxiety- or depression-related behaviors. These data highlight the unique GIRK channel subtype in VTA DA neurons as a possible therapeutic target for addiction.

\section{Introduction}

Dopamine (DA) neurons of the VTA are an integral part of the mesocorticolimbic system, a network of brain regions that medi-

Received Dec. 11, 2018; revised Feb. 17, 2019; accepted Feb. 22, 2019.

Author contributions: N.M.M., E.M.F.d.V., and K.W. designed research; N.M.M. performed research; N.M.M. analyzed data; N.M.M. wrote the paper; E.M.F.d.V. contributed unpublished reagents/analytic tools; K.W. edited the paper.

This work was supported by National Institutes of Health Grant DA034696 to K.W. and Grant DA041767 to N.M.M. We thank Nicholas Carlblom, Hannah Oberle, Zhilian Xia, and JingYing Zhang for care of the mouse colony; Dr. Megan Tipps for providing training in intracranial surgeries and discussing the manuscript; Dr. Yasushi Nakagawa for assistance with the immunohistochemistry studies; Nihan Gencerliler for helping with the design and initial testing of the GIRK3 expression vector; and Dr. Mark Sanders and Yung Kim (University of Minnesota University Imaging Centers) for microscopy support.

The authors declare no competing financial interests. ates behavioral responses to reward and drugs of abuse, including cocaine (Juarez and Han, 2016). Cocaine inhibits membrane monoamine transporters, including the DA transporter (DAT) (Rocha, 2003; Hall et al., 2004). As a result, cocaine increases DA levels in brain regions receiving dopaminergic projections (e.g., NAc), and locally within the VTA (Di Chiara and Imperato, 1988; Aragona et al., 2008). Cocaine exposure engages inhibitory G protein signaling in VTA DA neurons, including that mediated by somatodendritic $D_{2} D A$ autoreceptors $\left(D_{2} R s\right)$ and $G A B A_{B}$

Correspondence should be addressed to Kevin Wickman atwickm002@umn.edu. https://doi.org/10.1523/JNEUROSCI.3101-18.2019

Copyright $\odot 2019$ the authors 
receptors $\left(G_{A B A} R s\right)$. Elevated VTA DA levels stimulate $D_{2} R s$ (Brodie and Dunwiddie, 1990; Ford, 2014), whereas GABAergic inputs activate $\mathrm{GABA}_{\mathrm{B}}$ Rs on VTA DA neurons (Edwards et al., 2017). The direct inhibitory effect of $D_{2} R$ and $G_{A B A} R$ activation on VTA DA neurons is mediated largely by activation of $G$ protein-gated inwardly rectifying $\mathrm{K}^{+}$(GIRK/Kir3) channels (Cruz et al., 2004; Labouèbe et al., 2007; Arora et al., 2010). Whereas most neuronal GIRK channels contain GIRK1 and GIRK2 subunits (Luján et al., 2014), VTA DA neurons express a GIRK2/GIRK3 heteromeric channel (Cruz et al., 2004).

Work with knockout mice suggests that behavioral sensitivity to cocaine is inversely proportional to the strength of GIRKdependent signaling in DA neurons. Girk $2^{-1-}$ mice exhibit increased locomotor responses to cocaine and morphine (Arora et al., 2010; Kotecki et al., 2015) and altered cocaine self-administration (Morgan et al., 2003), as do mice lacking GIRK channels in DA neurons (DATCre $(+)$ :Girk $2^{f l f l}$ mice) (Kotecki et al., 2015; McCall et al., 2017). However, Girk2 ${ }^{-1-}$ mice exhibit an array of other behavioral phenotypes (Signorini et al., 1997; Blednov et al., 2001, 2003; Marker et al., 2004, 2005; Costa et al., 2005; Pravetoni and Wickman, 2008), as well as adaptations in excitatory and inhibitory neurotransmission in multiple rewardassociated neuron populations (Arora et al., 2010; Hearing et al., 2013), making it challenging to attribute changes in cocainerelated behavior to a specific population. While DATCre $(+)$ : Girk $2^{f l f l}$ mice afford increased cell specificity over Girk ${ }^{-1-}$ mice, GIRK-dependent signaling in all DA neurons, including those in the VTA, substantia nigra, and hypothalamus (Meister and Elde, 1993; Lorang et al., 1994; Demaria et al., 2000), is likely altered in this model.

Suppression of inhibitory G protein signaling in the VTA by pertussis toxin enhances the behavioral effects of cocaine (Steketee and Kalivas, 1991), suggesting that this signaling tempers behavioral sensitivity to cocaine. Notably, GIRK-dependent signaling in VTA DA neurons following psychostimulant exposure is decreased through channel internalization (Arora et al., 2011; Munoz et al., 2016). The strength of GIRK channel activity in VTA DA neurons is also modulated by neuronal excitability, with large depolarization events (e.g., phasic DA neuron firing) potentiating GIRK-dependent signaling, and hyperpolarization or tonic DA neuron firing reducing GIRK-dependent signaling (Lalive et al., 2014). These observations converge on a working model wherein in vivo psychostimulant exposure inhibits DA neurons via $G A B A_{B} R$ and $D_{2} R$ activation, leading to decreased strength of inhibitory $G$ protein signaling mediated by GIRK channel activation and, consequently, increased behavioral sensitivity to cocaine (Hearing et al., 2012; Marron Fernandez de Velasco et al., 2015; Rifkin et al., 2017).

Here, we used viral and genetic approaches to determine how the strength of GIRK channel activity in VTA DA neurons influences behavioral sensitivity to cocaine in mice. Because VTA DA neurons project to a number of brain regions implicated in anxiety and depression, including the hippocampus, amygdala, and PFC, and activation of DA receptors in these brain regions influences anxiety- and depression-like behaviors (Zarrindast and Khakpai, 2015; Belujon and Grace, 2017), we also asked whether manipulation of GIRK channel activity in VTA DA neurons impacted negative affective behavior. We found that, while anxiety and depression-related behaviors were unaltered by our manipulations, behavioral sensitivity to cocaine was inversely related to the strength of GIRK-dependent signaling in VTA DA neurons.

\section{Materials and Methods}

Mice. All studies were approved by the Institutional Animal Care and Use

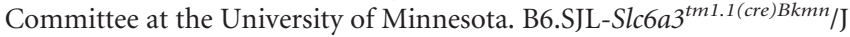
(stock \#006660, The Jackson Laboratory, RRID:IMSR_JAX:006660), hereafter referred to as DATCre $(+)$ mice, heterozygous for Cre, were used in all viral manipulation studies. This DATCre line has been widely used for the selective viral manipulation of DA neurons, offers improved selective targeting of dopaminergic over other available DA neurontargeting Cre lines, and does not exhibit altered DAT expression in heterozygotes (Bäckman et al., 2006; Lammel et al., 2015; Stuber et al., 2015). The generation of DATCre:Girk $2^{f l f l}$ mice was described previously (Kotecki et al., 2015). All mice for this study were bred in-house. Male and female mice were used for all studies, with groups balanced by sex. All mice were maintained on a $12 \mathrm{~h}$ light/dark cycle, and were provided ad libitum access to food and water.

Reagents. Baclofen, CGP54626, quinpirole, sulpiride, Triton-X, and DPX were purchased from Sigma-Aldrich. Cocaine was obtained through Boynton Health Pharmacy at the University of Minnesota. Saline (0.9\%) was purchased from Baxter Healthcare. Normal donkey serum was purchased from Gemini Bio-Products. The anti-TH antibody, made in sheep, was purchased from PelFreez (catalog \#P60101-0, RRID: AB_461070); and the anti-GFP antibody, made in chicken, was purchased from Abcam (catalog \#ab13970, RRID:AB_300798). Donkey anti-sheep Cy5 (catalog \#703-225-155, RRID:AB_2340370) and donkey anti-chicken Cy2 (catalog \#713-175-147, RRID:AB_2340730) secondary antibodies were purchased from Jackson ImmunoResearch Laboratories. All viruses were produced by the University of Minnesota Viral Vector and Cloning Core (Minneapolis). AAV8-DIO-hSyn-GIRK2cIRES-GFP and AAV8-DIO-hSyn-GIRK3-IRES-GFP vectors were used to overexpress GIRK2 and GIRK3, respectively, in a Cre-dependent manner. Cre-dependent viruses expressing GFP (AAV8-DIO-hSyn-GFP) or mCherry (AAV8-DIO-hSyn-mCherry) served as controls.

Intracranial viral manipulations. Mice ( $\geq 45 \mathrm{~d}$ ) were placed in a stereotaxic frame (David Kopf Instruments) under isoflurane anesthesia. Microinjectors, made by affixing a 33-gauge stainless-steel hypodermic tube within a shorter 26-gauge stainless-steel hypodermic tube, were attached to polyethylene-20 tubing affixed to $10 \mu \mathrm{l}$ Hamilton syringes, and were lowered through burr holes in the skull to the VTA (from bregma: -2.6 $\mathrm{mm}$ anteroposterior, $\pm 0.6-0.7 \mathrm{~mm}$ mediolateral, $-4.7 \mathrm{~mm}$ dorsoventral); $500 \mathrm{nl}\left(2.16 \times 10^{13}\right.$ to $3.26 \times 10^{14}$ genocopies $\left./ \mathrm{ml}\right)$ of virus per side was injected over $5 \mathrm{~min}$. Microinjectors were left in place for $10 \mathrm{~min}$ following infusion to reduce solution backflow along the infusion track. Immunohistochemistry, slice electrophysiology, and behavioral experiments were performed 3 weeks after surgery to allow for full recovery and viral expression.

Immunohistochemistry. Mice were anesthetized with ketamine/xylazine and transcardially perfused with $\mathrm{PB}$, followed by $4 \%$ PFA in $0.1 \mathrm{M}$ $\mathrm{PB}$. Brains were extracted and postfixed overnight in $4 \%$ PFA in PB at $4^{\circ} \mathrm{C}$. Brains were then rinsed with $\mathrm{PB}$ and transferred to $30 \%$ sucrose in PB. Horizontal slices of VTA $(50 \mu \mathrm{m})$ were prepared using a sliding microtome (SM 2000R, Leica Microsystems) and stored in PB at $4^{\circ} \mathrm{C}$. Three slices, separated by $\sim 350 \mu \mathrm{m}$, were stained for each mouse; 3 separate mice per viral condition were analyzed. All steps were performed at room temperature, with free-floating slices, in a 24 -well plate on a rocker. Slices were rinsed in PBS $(3 \times 10 \mathrm{~min})$ and incubated in blocking solution ( $0.3 \%$ Triton-X and 3\% normal donkey serum in PBS) for $2 \mathrm{~h}$. Slices were then incubated overnight in blocking solution containing a sheep anti-TH antibody (1:500) and chicken anti-GFP antibody (1:500). Slides were rinsed with PBS $(3 \times 10 \mathrm{~min})$ and then incubated in secondary antibodies diluted in PBS (1:500 donkey anti-sheep Cy5; 1:200 donkey anti-chicken Cy2) for $2 \mathrm{~h}$, after which slices were rinsed with PBS $(6 \times 10 \mathrm{~min})$. Slices were mounted on glass slides and allowed to fully dry before being dehydrated with 3 min incubations in: 70\% EtOH, 80\% $\mathrm{EtOH}, 95 \% \mathrm{EtOH}, 100 \% \mathrm{EtOH}$, and xylene. Slides were mounted using DPX and allowed to dry. Slides were imaged by the University Imaging Center at the University of Minnesota on an A1R confocal microscope (Nikon) imaged with the Galvano scanner using $488 \mathrm{~nm}$ and $567 \mathrm{~nm}$ lines and filters. The images were collected using a $10 \times, 0.45 \mathrm{NA}$ plan 
Apo objective at $1024 \times 1024$ pixels, with a zoom of $1 \times$ using the Scan Large Area feature using Perfect Focus. Four $15 \mu \mathrm{m} z$ steps were collected, and images were generated in Nis-Elements AR (Nikon) using Extended Depth of Focus. To assess the fidelity and penetrance of the viruses, the Cy2 and Cy5 channels were merged using Fiji (https://imagej. nih.gov/ij/), with Cy2 as green and Cy5 as magenta. In the region of viral expression with in the VTA, the number of $\mathrm{Cy} 22^{+}$neurons, $\mathrm{Cy} 5{ }^{+}$neurons, and $\mathrm{Cy} 2{ }^{+} / \mathrm{Cy} 5{ }^{+}$neurons were quantified using the cell counter plugin in Fiji. Representative images in Figure 1 were taken with an IX81ZDC2 Olympus microscope at $20 \times$.

Slice electrophysiology. Somatodendritic currents were evaluated in both behaviorally naive mice ( 3 weeks following viral injection; 66-73 d) and at the conclusion of behavioral testing (5-6 weeks following viral injection; 80-110 d). Horizontal slices $(225 \mu \mathrm{m})$ containing the VTA were prepared in ice-cold sucrose ACSF, as described previously (Kotecki et al., 2015; McCall et al., 2017). Neurons medial to the medial terminal nucleus of the accessory optic tract (MT), and identified via Credependent viral-mediated fluorescence, were targeted for analysis. Whole-cell data were acquired using a Multiclamp 700A amplifier and pCLAMP version 9.2 software (Molecular Devices). $I_{h}$ amplitude was assessed using a $1 \mathrm{~s}$ voltage ramp $(-60$ to $-120 \mathrm{mV})$. Spontaneous activity was measured in current-clamp mode $(\mathrm{I}=0)$ for $1 \mathrm{~min}$. For rheobase assessments, cells were held in current-clamp mode and given $1 \mathrm{~s}$ current pulses, beginning at $-80 \mathrm{pA}$ and progressing in $20 \mathrm{pA}$ increments until spiking was elicited. Rheobase was defined as the minimum current step evoking one or more action potentials. Agonist-induced somatodendritic currents were measured at a holding potential $\left(\mathrm{V}_{\text {hold }}\right)$ of $-60 \mathrm{mV}$. All command potentials factored in a junction potential of -15 $\mathrm{mV}$ predicted using JPCalc software (Molecular Devices). Series and membrane resistances were tracked throughout the experiment. If series resistance was unstable, the experiment was excluded from analysis.

Behavior. All mice in this study were evaluated in elevated plus maze (EPM), forced swim test (FST), and open field cocaine-induced locomotor activity assays in the light cycle, in this order, with at least $1 \mathrm{~d}$ separating each test. For the EPM test, mice were transferred to the testing room $1 \mathrm{~h}$ before evaluation. Mice were placed in the middle of the maze, facing a corner between an open and closed arm. Video was recorded using ANY-Maze Maze 5.2 (Stoelting) software and a STC-TB83USB-AS camera (Sensor Technologies America). Mice were allowed to freely explore the maze for $5 \mathrm{~min}$. Between tests, the maze was wiped down with $70 \% \mathrm{EtOH}$. Time in arms, number of arm entries, and total distance traveled were analyzed using ANY-Maze software. For the FST study, mice were transferred to the testing room $1 \mathrm{~h}$ before evaluation. Mice were placed in a $4 \mathrm{~L}$ beaker filled with $\sim 1.5 \mathrm{~L}$ of $23^{\circ} \mathrm{C}$ water, for $6 \mathrm{~min}$. Video was recorded using ANY-Maze software and a C615 camera (Logitech), and the latency to first immobile bout and total immobility time during the final 4 min of testing were analyzed by hand using ANY-Maze software. Cocaine-induced activity was assessed in open field activity chambers (Med Associates), as described previously (Pravetoni and Wickman, 2008). In brief, subjects were acclimated over $3 \mathrm{~d}$, during which the animals were handled on $1 \mathrm{~d}$ and exposed to intraperitoneal injection (saline) on $2 \mathrm{~d}$, and then placed in the open field. Distance traveled during the $60 \mathrm{~min}$ period following saline injection on the last acclimation day was taken as baseline activity. Cocaine-induced activity was then assessed following administration of three cocaine doses $(3,15$, and $30 \mathrm{mg} / \mathrm{kg}$ i.p.), with each dose separated by $3 \mathrm{~d}$, as described previously (Kotecki et al., 2015).

Viral targeting accuracy was assessed in all subjects using fluorescence microscopy before post hoc slice electrophysiology experiments. To assess and summarize the expression pattern and spread of virus, $2 \times$ images of brightfield and fluorescent viral expression were taken with an IX81ZDC2 Olympus microscope, overlaid, and matched to figures in the horizontal atlas of the mouse brain (Franklin and Paxinos, 2008), and spread patterns were summarized. The pattern of viral spread for each mouse was overlaid on a simplified version of the atlas, with each spread pattern at $10 \%$ transparency to provide a sense of viral spread for individual subjects, and cumulatively for the study. Only data from mice in which the majority $(>80 \%)$ of expression was confined to the VTA, with limited or no diffusion to adjacent structures (i.e., SN pars compacta), were analyzed in behavioral studies.

Experimental design and statistical analyses. Data are presented throughout as mean \pm SEM. Statistical analyses were performed using Prism 5 (GraphPad Software) and SigmaPlot 11.0 (Systat Software). All studies involved balanced groups of male and female mice. Data were analyzed first for effects of sex and viral condition, or sex and genotype, using two-way ANOVA when those were the only variables. For cocaine locomotor activity data with multiple testing days, the interaction of sex for each virus or genotype group was assessed using two-way repeatedmeasures ANOVA. When there was no effect of sex, male and female data were pooled. When there was an effect of sex or an interaction of sex with another factor, male and female data were analyzed and presented separately. Data were analyzed by $t$ test, Mann-Whitney $U$ test, two-way ANOVA, or repeated-measures ANOVA, with Bonferroni or post hoc tests, as appropriate. Differences were considered significant if $p<0.05$.

\section{Results \\ Viral manipulation of GIRK channel activity in VTA DA neurons}

To manipulate the strength of GIRK channel activity in VTA DA neurons, we used a Cre-dependent viral strategy to overexpress GIRK2 or GIRK3 in adult DATCre $(+)$ mice. We predicted that the overexpression of GIRK2 in VTA DA neurons would enhance GIRK channel activity, as GIRK2 can form functional homomeric channels and mediates the forward trafficking of GIRK channels (Lesage et al., 1995; Ma et al., 2002). Conversely, we predicted that the overexpression of GIRK3 would suppress GIRK channel activity, as GIRK3 is unable to form functional homomeric channels, it harbors a lysosomal targeting sequence that can promote GIRK channel internalization, and its presence correlates with decreased sensitivity of the VTA DA GIRK channel to $\mathrm{GABA}_{\mathrm{B}} \mathrm{R}$-induced activation (Lesage et al., 1995; Ma et al., 2002; Labouèbe et al., 2007; Lunn et al., 2007).

We infused Cre-dependent control, GIRK2, or GIRK3 expression vectors into the VTA of DATCre $(+)$ mice (Fig. $1 A$ ). Following viral infusion (3 weeks), we performed immunohistochemistry with horizontal sections containing the VTA, to assess the fidelity of our viral manipulations (Fig. $1 B-E$ ). Similar to published reports involving DATCre $(+)$ mice (Lammel et al., 2015), we found that the vast majority of GFP-positive neurons examined in slices from mice treated with control (96\%), GIRK2 (93\%), or GIRK3 (92\%) vectors expressed $\mathrm{TH}\left(\mathrm{TH}^{+}\right.$; Fig. $\left.1 C-E\right)$. Moreover, $75 \%$ of $\mathrm{TH}^{+}$neurons in the region of viral expression were also $\mathrm{GFP}^{+}$, as measured in sections from DATCre $(+)$mice treated with control vector. Thus, our approach yielded a selective manipulation of VTA DA neurons in adult mice.

To assess the functional consequences of overexpressing GIRK2 or GIRK3 in VTA DA neurons, we measured somatodendritic currents in acutely isolated brain slices evoked by a maximal concentration of the $\mathrm{GABA}_{\mathrm{B}} \mathrm{R}$ agonist baclofen $(200 \mu \mathrm{M})$, as GIRK channels mediate $\sim 80 \%$ of this inhibitory current in VTA DA neurons (Labouèbe et al., 2007; Arora et al., 2010; Kotecki et al., 2015). As predicted, overexpression of GIRK2 in VTA DA neurons yielded enhanced $\mathrm{GABA}_{\mathrm{B}} \mathrm{R}$-dependent currents compared with currents from control VTA DA neurons (Fig. $1 F$ ). Overexpression of GIRK2 did not, however, yield significant differences in apparent capacitance, membrane resistance, $\mathrm{I}_{\mathrm{h}}$, or spontaneous activity (Table 1 ). There was a significant increase in rheobase (Table 1), however, suggesting that GIRK2 overexpression decreased baseline neuronal excitability. Conversely, GIRK3 overexpression in VTA DA neurons suppressed $\mathrm{GABA}_{\mathrm{B}} \mathrm{R}$ dependent currents (Fig. $1 G$ ). There were no significant differences in apparent capacitance, membrane resistance, $I_{h}$, rheobase, or 


\section{A Virus infused into VTA \\ Immunohistochemistry Electrophysiology}
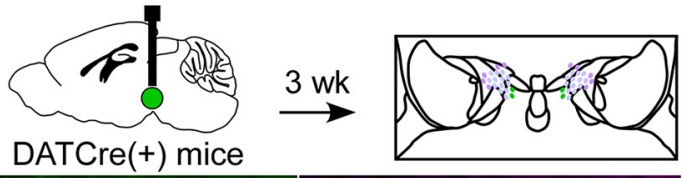

or

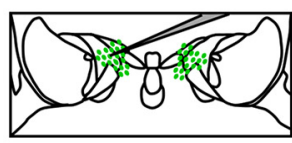

B
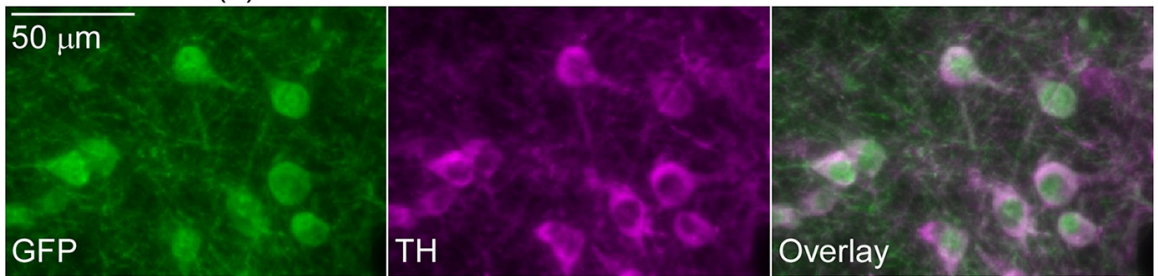

C

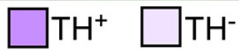

D

E

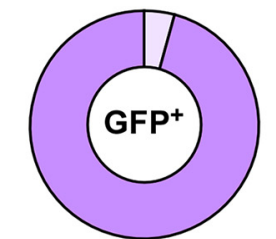

Control
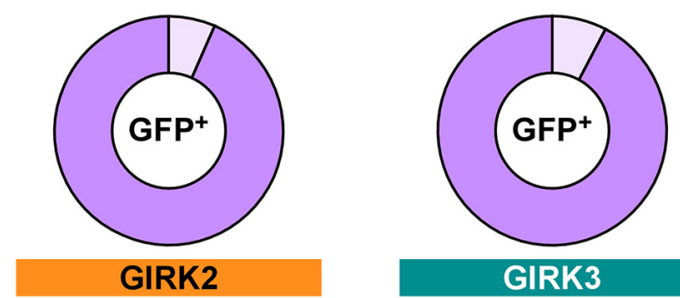

GIRK3
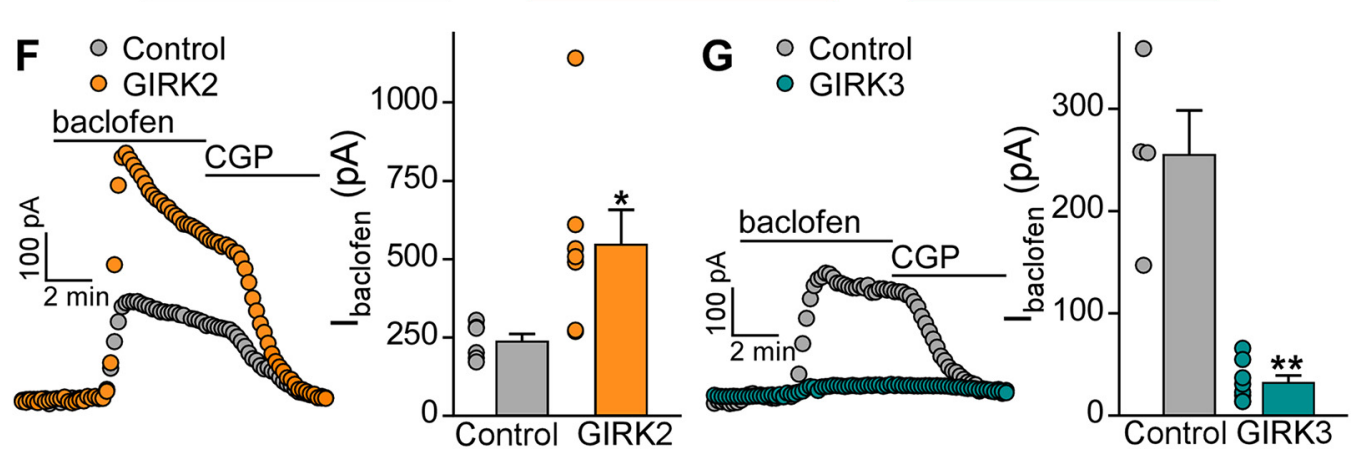

Figure 1. Viral overexpression of GIRK channel subunits in VTA DA neurons. $A$, DATCre $(+)$ mice were given intra-VTA infusion of Cre-dependent control, GIRK2, or GIRK3 vector. Following viral injection ( $3 \mathrm{w})$, mice were processed for either immunohistochemistry or slice electrophysiology. $\boldsymbol{B}$, Control virus expression in the VTA of DATCre $(+)$ mice. In the region of viral infusion, the percentage of $\mathrm{GFP}^{+}$neurons that were also dopaminergic $\left(\mathrm{TH}^{+}\right)$was calculated to determine viral fidelity in control (C), GIRK2 (D), and GIRK3 (E) viral conditions. $\boldsymbol{F}$, The overexpression of GIRK2 ( $n=7$ cells from 3 mice, $547 \pm 111 \mathrm{pA}$ ) enhanced $\mathrm{GABA}_{\mathrm{B}} \mathrm{R}$ currents compared with cells expressing a control virus ( $n=6$ cells from $2 \mathrm{mice}, 238 \pm 24 \mathrm{pA} ;$ Mann - Whitney $U$ test, $U=6, p=0.035$ ). G, The overexpression of GIRK3 ( $n=8$ cells from 5 mice, $33 \pm 7 \mathrm{pA}$ ) diminished GABA $\mathrm{B}$ currents compared with cells expressing a control virus ( $n=4$ cells from 3 mice, $255 \pm 44 \mathrm{pA}$; Mann-Whitney $U$ test, $U=0, p=0.004) .{ }^{*} p<0.05 .{ }^{* *} p<0.01$.

Table 1. Baseline electrophysiological parameters for neurons in Figure 1

\begin{tabular}{|c|c|c|c|c|c|c|c|}
\hline & $n$ & $C_{m}(p F)$ & $\mathrm{R}_{\mathrm{m}}(\mathrm{m} \Omega)$ & $I_{h}(p A)$ & Rheobase (pA) & Active neurons & Frequency $(\mathrm{Hz})$ \\
\hline Control & 6 & $47 \pm 4$ & $367 \pm 70$ & $99 \pm 38$ & $-27 \pm 11$ & $4 / 6$ & $1.85 \pm 0.51$ \\
\hline GIRK2 & 7 & $\begin{array}{l}48 \pm 7 \\
t_{(11)}=0.290 \\
p=0.778\end{array}$ & $\begin{array}{l}230 \pm 55 \\
t_{(11)}=1.547 \\
p=0.150\end{array}$ & $\begin{array}{l}32 \pm 12 \\
U=12 \\
p=0.234\end{array}$ & $\begin{array}{l}43 \pm 22^{*} \\
t_{(11)}=2.671 \\
p=0.022\end{array}$ & $4 / 7$ & $\begin{array}{l}1.17 \pm 0.27 \\
t_{(6)}=1.187 \\
p=0.280\end{array}$ \\
\hline Control & 4 & $48 \pm 1$ & $243 \pm 119$ & $191 \pm 85$ & $-15 \pm 25$ & $4 / 4$ & $2.12 \pm 0.49$ \\
\hline GIRK3 & 8 & $\begin{array}{l}40 \pm 6 \\
U=6.5 \\
p=0.125\end{array}$ & $\begin{array}{l}383 \pm 136 \\
t_{(10)}=0.659 \\
p=0.523\end{array}$ & $\begin{array}{l}58 \pm 13 \\
U=7 \\
p=0.154\end{array}$ & $\begin{array}{l}-8 \pm 14 \\
t_{(10)}=0.284 \\
p=0.783\end{array}$ & $7^{a} / 8$ & $\begin{array}{l}2.40 \pm 0.66 \\
t_{(8)}=0.316 \\
p=0.760\end{array}$ \\
\hline
\end{tabular}

${ }^{a}$ One burst firing neuron was included in the count of neurons spontaneously active for the GIRK3 condition but was not included in firing frequency analysis. ${ }^{*} p<0.05$.

spontaneous activity following GIRK3 overexpression (Table 1). Thus, the overexpression of GIRK2 or GIRK3 in VTA DA neurons bidirectionally alters the strength of GIRK-dependent signaling.

Negative affective behaviors and cocaine sensitivity in DATCre:Girk $2^{f l / f l}$ mice

Previously, we reported that the genetic ablation of Girk2 in DA neurons correlated with an increased acute locomotor response to cocaine (McCall et al., 2017). Intriguingly, the excitability of VTA DA neurons has also been shown to influence negative affective behavior (Anstrom and Woodward, 2005; Nestler and Carlezon, 2006; Krishnan et al., 2007; Cao et al., 2010; Chaudhury et al., 2013; Russo and Nestler, 2013; Tye et al., 2013; Polter and Kauer, 2014). Thus, we sought to assess how manipulation of GIRK channel activity in VTA DA neurons altered performance in anxiety (EPM), depression (FST), and cocaine-induced motor 

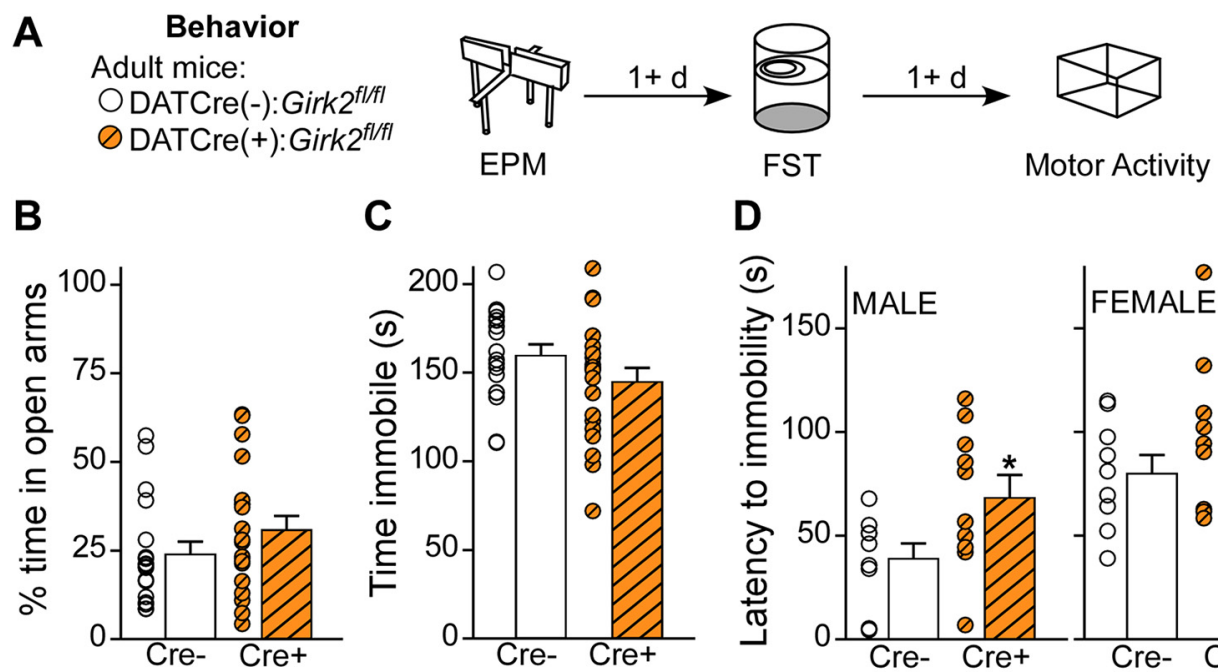

C

D
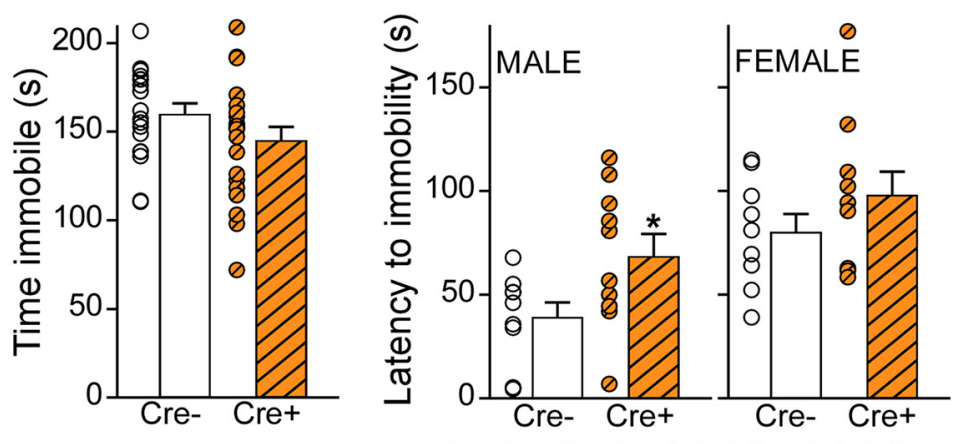

E

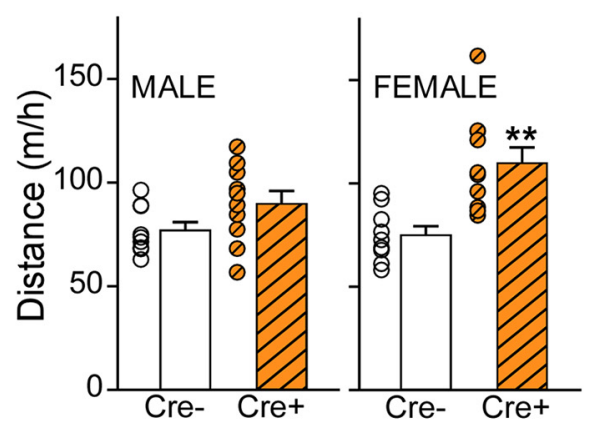

$\mathbf{F}$
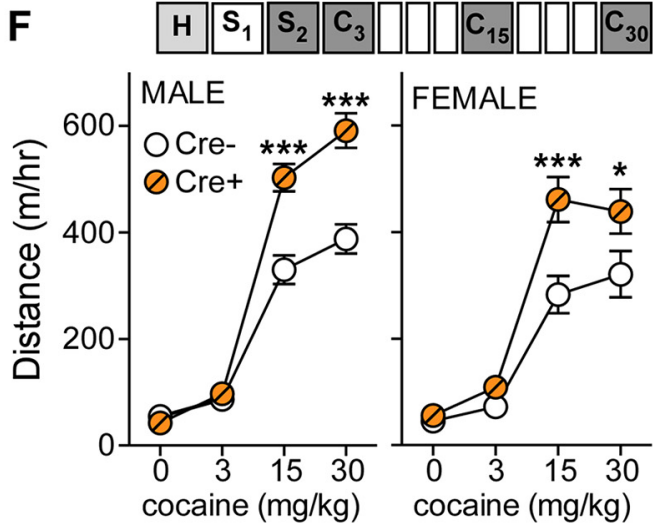

Figure 2. Negative affective and cocaine locomotor behavior in DATCre(+):Girk2 $2^{f / / f l}$ mice. A, Adult male and female DATCre( $(-): G i r k 2^{f / / f l}$ and DATCre( + ):Girk2 $2^{f / f l}$ mice were tested in EPM, FST, and cocaine locomotor activity tests, with each task separated by at least $1 \mathrm{~d}$. $B$, Percent time in open arms in the EPM is not different in Cre ${ }^{-}(n=18,24 \pm 4 \%)$ and Cre ${ }^{+}(n=20,31 \pm 4 \%$; Mann-Whitney $U$ test, $U=132, p=0.165)$. C, Time immobile for $\mathrm{Cre}^{-}(n=18,160 \pm 6 \mathrm{~s})$ and $\mathrm{Cre}^{+}(n=20,145 \pm 8 \mathrm{~s})$ mice in the FST does not differ $\left(t\right.$ test, $\left.t_{(36)}=1.499, p=0.143\right) . \boldsymbol{D}$, Latency to immobility in male $\mathrm{Cre}^{+}(n=10,68 \pm 11 \mathrm{~s})$ mice is greater than in $\mathrm{Cre}^{-}$mice $\left(n=9,39 \pm 7 \mathrm{~s} ; t\right.$ test, $\left.t_{(17)}=2.210, p=0.041\right)$, while there is no difference in latency to immobility between $\mathrm{Cre}^{-}(n=9,80 \pm 9 \mathrm{~s})$ and $\mathrm{Cre}^{+}\left(n=10,98 \pm 11 \mathrm{~s} ; \mathrm{ttest} t_{(17)}=1.213, p=0.242\right)$ mice. $\boldsymbol{E}$, There is no significant difference in distance moved on the handling habituation day between male $\mathrm{Cre}^{-}(n=9,77 \pm 4 \mathrm{~m} / \mathrm{h})$ and $\mathrm{Cre}^{+}\left(n=10,90 \pm 6 \mathrm{~m} / \mathrm{h} ; t\right.$ test, $\left.t_{(17)}=1.774, p=0.094\right)$ mice. However, female $\mathrm{Cre}^{+}$mice $(n=10,110 \pm 8 \mathrm{~m} / \mathrm{h})$ moved significantly more than $\mathrm{Cre}{ }^{-}$ mice $\left(n=9,75 \pm 4 \mathrm{~m} / \mathrm{h} ; t\right.$ test, $\left.t_{(17)}=3.876, p=0.001\right) . F$, In male and female mice, distance traveled following injection of $0,3,15$, and $30 \mathrm{mg} / \mathrm{kg}$ cocaine resulted in an interaction between cocaine dose and genotype (males, two-way repeated-measures ANOVA, interaction between cocaine dose and virus, $F_{(3,51)}=13.557, p<0.001$; females, two-way repeated-measures ANOVA, interaction between cocaine dose and virus, $F_{(3,51)}=3.213, p=0.030$ ). Male $\mathrm{Cre}^{+}$mice moved significantly more than ( $\mathrm{re}^{-}$mice at $15 \mathrm{mg} / \mathrm{kg}$ (Bonferroni post hoc test $, t=5.863, p<0.001$ ) and $30 \mathrm{mg} / \mathrm{kg}$ (Bonferroni post hoc test, $t=6.907, p<0.001$ ) cocaine. Similarly, female Cre ${ }^{+}$mice moved significantly more than $\mathrm{Cre}^{-}$mice at $15 \mathrm{mg} / \mathrm{kg}$ (Bonferroni posthoc test $, t=4.249, p<$ 0.001 ) and $30 \mathrm{mg} / \mathrm{kg}$ (Bonferroni post hoc test, $t=2.809, p=0.006$ ) cocaine. ${ }^{*} p<0.05$. ${ }^{* *} p<0.01 .{ }^{* * *} p<0.001$.

activity tests (Fig. 2A). Because this behavioral battery approach had not been previously used by our laboratory, we evaluated DATCre $(+)$ :Girk $2^{f l f l}$ and DATCre $(-)$ :Girk $2^{f l / f l}$ mice before testing the impact of VTA DA neuron-specific GIRK channel manipulations.

DATCre $(+): G i r k 2^{f l f l}$ mice exhibited similar percent time in open arms of the EPM compared with DATCre $(-)$ :Girk $2^{f l f l}$ mice (Fig. 2B), and there were no genotype differences in percent time spent in closed arms $\left(\mathrm{Cre}^{-}, 63 \pm 3 \%\right.$; $\mathrm{Cre}^{+}, 59 \pm 4 \%, t$ test, $t_{(36)}$ $=0.820, p=0.418)$, number of entries into open arms (Cre ${ }^{-}$, $10 \pm 1$ entries; Cre ${ }^{+}, 10 \pm 1$ entries, Mann-Whitney test, $U=$ $150.5, p=0.393$ ), and number of entries into closed arms (Cre ${ }^{-}$, $11 \pm 1$ entries; Cre ${ }^{+}, 11 \pm 1$ entries; $t$ test, $t_{(36)}=0.7710, p=$ $0.446)$. Thus, loss of GIRK channel activity in DA neurons does not appear to influence anxiety-like behavior.

In the FST, we did not observe a difference in time immobile for DATCre(-):Girk2 $2^{f l f l}$ mice and DATCre $(+)$ :Girk $2^{f l / f l}$ mice (Fig. 2C). We did observe a main effect of sex in the latency to immobility measure (ANOVA, $F_{(1,34)}=12.67, p=0.001$ ), how- ever; and as such, these data were analyzed separately by sex (Fig. $2 D)$. While female mice did not display an effect of genotype on latency to immobility (Fig. 2D), male DATCre $(+)$ :Girk $2^{f l f l}$ mice exhibited a longer latency than male DATCre $(-)$ :Girk $2^{f l f l}$ mice, suggesting an antidepressive behavioral phenotype. Notably, the reduced time to immobility in male DATCre $(+)$ :Girk $2^{f l f l}$ mice (Fig. 2D) is consistent with a previous report, which found that male Cre ${ }^{+}$mice from a separately developed DATCre:Girk $2^{f l f l}$ mouse line displayed an antidepressive behavioral phenotype (Honda et al., 2018). Thus, GIRK channel activity in DA neurons appears to enhance depression-related behavior in male mice.

Finally, we assessed cocaine-induced motor activity in DATCre (+):Girk $2^{f l f l}$ mice (Fig. $2 A, E$ ). Similar to our previous study (McCall et al., 2017), we observed a significant interaction of sex and cocaine dose in DATCre $(+)$ :Girk $2^{f l f l}$ mice $\left(F_{(3,54)}=4.133\right.$, $p=0.010)$; as such, males and females were analyzed separately. We did not observe a difference in total distance traveled by males on the first day (handling $[\mathrm{H}]$ ) of exposure to the open field (Fig. $2 E)$; however, female $\mathrm{Cre}^{+}$mice traveled further than $\mathrm{Cre}^{-}$mice 
(Fig. 2E), an observation that aligns with our previous report (McCall et al., 2017). This genotype difference in female mice is not observed on saline day $2\left(\mathrm{~S}_{2}\right.$; Fig. $2 F, 0 \mathrm{mg} / \mathrm{kg}$ cocaine), suggesting that the significant effect on handling day may be driven by a difference in exploration, rather than purely motor activity. Similar to our previous findings with acute cocaine administration (McCall et al., 2017), male and female DATCre(+):Girk ${ }^{f l f l}$ mice exhibit increased locomotor activity at $15 \mathrm{mg} / \mathrm{kg}$ cocaine, and female $\mathrm{Cre}^{+}$mice do not respond to $30 \mathrm{mg} / \mathrm{kg}$ cocaine as much as male $\mathrm{Cre}^{+}$mice (Fig. $2 F$ ). Overall, our findings support the hypothesis that reduced GIRK channel activity in DA neurons increases behavioral sensitivity to cocaine.

\section{Reduced GIRK channel activity in VTA DA neurons increases cocaine sensitivity}

Having recapitulated findings related to depression-like behavior (Honda et al., 2018) and cocaine sensitivity (McCall et al., 2017) for DATCre:Girk $2^{f l f l}$ mice using this behavioral test battery, we next assessed the behavioral impact of viral suppression of GIRK channel activity in adult VTA DA neurons. To do this, we compared the behavioral performance of DATCre $(+)$ mice treated with control or GIRK3 overexpression vectors (Fig. 3A). No difference was detected between control and GIRK3 overexpression groups in percent time spent in open arms in the EPM (Fig. 3B). Additionally, there was no difference in percent time spent in closed arms (control, $53 \pm 5 \%$; GIRK3, $57 \pm 3 \%$; Mann-Whitney test, $U=109, p=0.706$ ), number of entries into open arms (control, $10 \pm 1$ entries; GIRK3, $9 \pm 1$ entries; $t$ test, $t_{(29)}=0.711, p=0.483$ ), or number of entries into closed arms (control, $10 \pm 1$ entries; GIRK3, $11 \pm 1$ entries; $t$ test, $t_{(29)}=$ $0.367, p=0.716)$. Similarly, no group differences were observed in total immobility time (Fig. $3 C$ ), or latency to immobility (control, $70 \pm 8 \mathrm{~s}$; GIRK3, $76 \pm 10 \mathrm{~s} ; t$ test, $\left.t_{(21)}=0.476, p=0.639\right)$ in the FST. No difference was observed in locomotor activity on the handling day or saline day 2 between control and GIRK3 overexpression conditions (Fig. $3 D, E$ ). We did, however, observe a significant interaction between cocaine dose and viral treatment, with DATCre $(+)$ mice treated with the GIRK3 virus exhibiting significantly enhanced locomotor activity at the $15 \mathrm{mg} / \mathrm{kg}$ cocaine dose (Fig. 3E). Thus, viral suppression of GIRK channel activity in adult VTA DA neurons elicits a selective and dosedependent enhancement of cocaine-induced motor activity, without impacting anxiety- or depression-like behaviors.

Following behavioral testing, mice were prepared for slice electrophysiological evaluation, and the extent of viral spread was summarized for control and GIRK3 overexpression conditions (Fig. $3 F$ ). As we found in behaviorally naive subjects (Fig. $1 G$ ), $\mathrm{GABA}_{\mathrm{B}} \mathrm{R}$-dependent somatodendritic currents were significantly smaller in fluorescent VTA neurons in the GIRK3 overexpression group compared with controls (Fig. $3 G$ ). Similarly, somatodendritic currents evoked by a maximal concentration of the $D_{2} R$ agonist quinpirole $(20 \mu \mathrm{M})$ were significantly decreased in the GIRK3 overexpression group (Fig. $3 H$ ). Thus, results from our initial viral validation and post hoc analysis suggest that GIRK3 overexpression suppresses GIRK channel activity evoked by $\mathrm{GABA}_{\mathrm{B}} \mathrm{R}$ and $\mathrm{D}_{2} \mathrm{R}$ in VTA DA neurons throughout the entire duration of behavioral testing.

\section{Increased GIRK channel activity in VTA DA neurons decreases cocaine sensitivity}

We next assessed the behavioral effect of enhancing GIRK channel activity in VTA DA neurons (Fig. 4A). There was no difference between control and GIRK2 overexpression groups in percent time spent in open arms of the EPM (Fig. 4B). Additionally, there was no difference in percent time spent in closed arms (control, $53 \pm 4 \%$; GIRK2, $57 \pm 5 \%$; $t$ test, $t_{(31)}=0.692, p=$ 0.494 ), number of entries into open arms (control, $11 \pm 1$ entries; GIRK2, $9 \pm 1$ entries; $t$ test, $t_{(31)}=1.107, p=0.277$ ), or number of entries into closed arms (control, $10 \pm 1$ entries; GIRK2, $10 \pm$ 1 entries; $t$ test, $t_{(31)}=0.254, p=0.801$ ). We did not observe a significant difference in time immobile during the FST (Fig. 4C), nor did we observe any difference in latency to immobility between control (61 $\pm 6 \mathrm{~s})$ and GIRK2 (69 $\pm 11 \mathrm{~s}$; Mann-Whitney test, $U=83, p=0.519)$ viral conditions. We also found no difference in locomotor activity on the handling day or saline day 2 (Fig. $4 D, E$ ). There was a significant interaction of viral condition and cocaine dose, with mice in the GIRK2 overexpression group responding significantly less at the 15 and $30 \mathrm{mg} / \mathrm{kg}$ cocaine doses (Fig. 4E). Thus, increasing the strength of GIRK channel activity in VTA DA neurons decreases behavioral sensitivity to cocaine, without impacting anxiety- or depression-like behaviors.

Following behavioral testing, control and GIRK2 overexpression mice were prepared for slice electrophysiological evaluation, and the extent of viral spread was summarized for control and GIRK2 overexpression conditions (Fig. $4 F$ ). Similar to our electrophysiological findings before behavioral testing (Fig. $1 F$ ), $\mathrm{GABA}_{\mathrm{B}} \mathrm{R}$-dependent currents were significantly enhanced following GIRK2 overexpression, compared with control virus (Fig. $4 G$ ). However, $\mathrm{D}_{2} \mathrm{R}$-GIRK currents in the GIRK2 overexpression condition were not significantly different from controls (Fig. $4 H$ ). The $\mathrm{D}_{2} \mathrm{R}$-dependent response was heterogeneous, however, and the range of data in the GIRK2 overexpression group was substantially larger than that of the control condition ( $F$ test to compare variances, $F_{(7,7)}=6.774, p=0.022$; Fig. $4 H$ ). This suggests that the overexpression of GIRK2 could alter the strength of $\mathrm{D}_{2} \mathrm{R}$-GIRK channel-mediated signaling in some, but not all, DA neurons.

\section{Discussion}

Here, we used a viral approach to bidirectionally manipulate the strength of GIRK channel activity in VTA DA neurons of adult mice. We found that behavioral sensitivity to cocaine was inversely proportional to the strength of GIRK channel activity in VTA DA neurons, whereas negative affective behaviors were unaltered by VTA DA neuron-specific GIRK channel manipulations. These findings show that GIRK channel activity in VTA DA neurons can influence behavioral sensitivity to cocaine and suggest that manipulation of these channels could represent a new therapeutic approach to treating certain aspects of addiction. This prospect is enhanced by the fact that the GIRK2/GIRK3 channel subtype expressed in DA neurons is unique (Cruz et al., 2004; Labouèbe et al., 2007; Arora et al., 2010). Given that VTA DA neurons appear to be most influential in the early phase of addiction (i.e., binge/intoxication) (Volkow et al., 2012), an agonist selective for GIRK2/GIRK3 channels might be expected to suppress drug reward and acquisition of self-administration, without altering negative affective behavior.

\section{GIRK channel activity in VTA DA neurons shapes behavioral sensitivity to cocaine}

Our previous work demonstrated genetic ablation of GIRK channels globally or in DA neurons increased behavioral sensitivity to cocaine (Arora et al., 2010; McCall et al., 2017). Similarly, the DA neuron-specific ablation of sorting nexin 27 (SNX27), a cytoplasmic protein that interacts with the PDZ-binding motifs of 

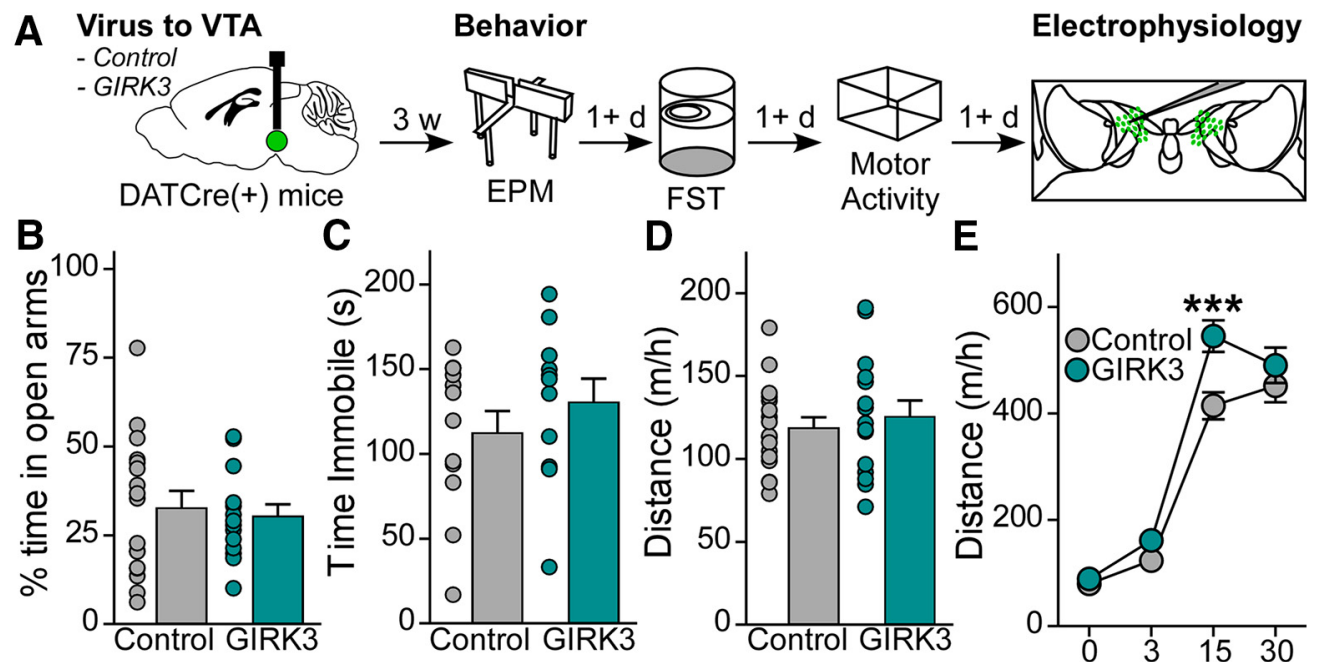

E
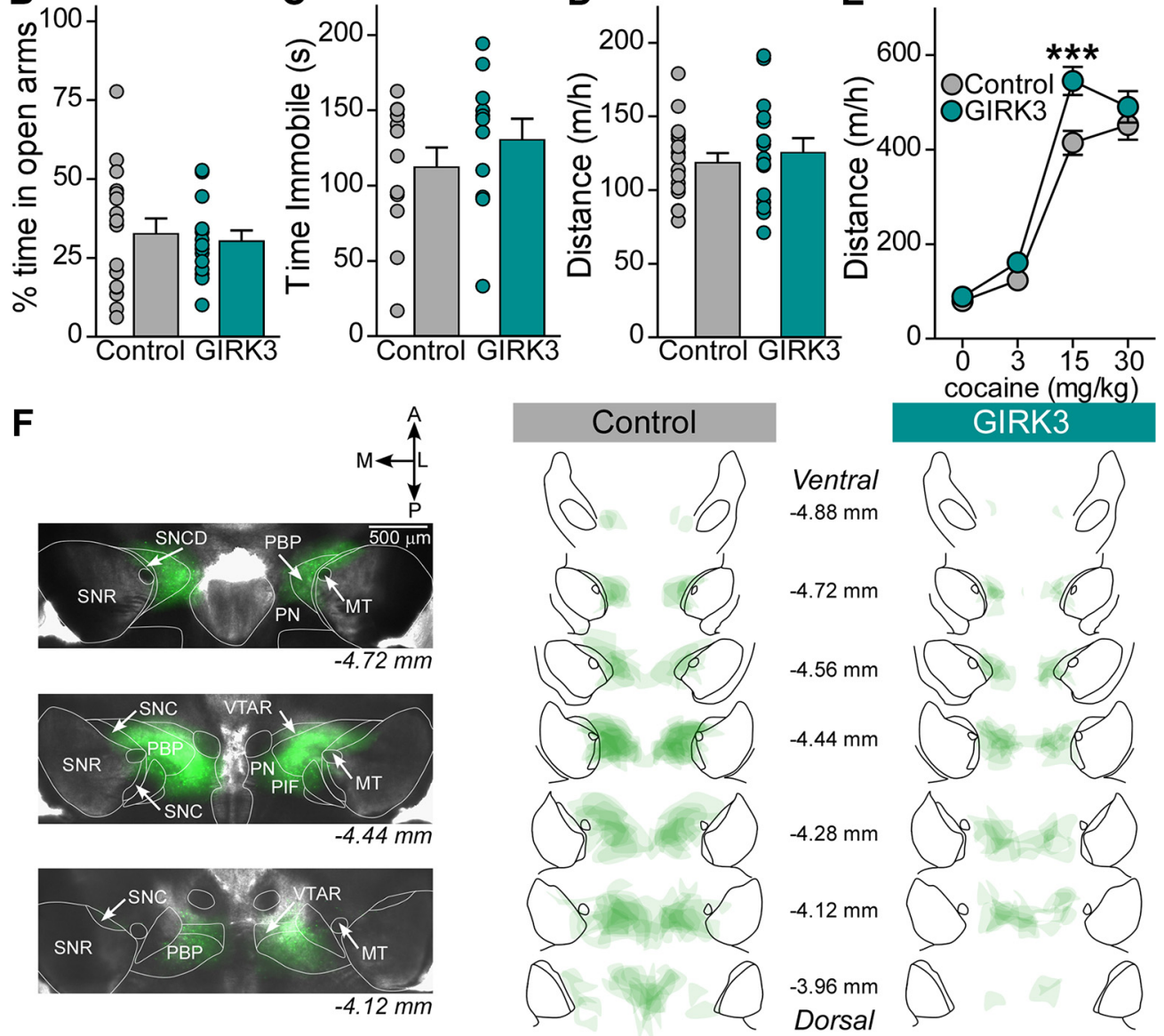

$-4.72 \mathrm{~mm}$
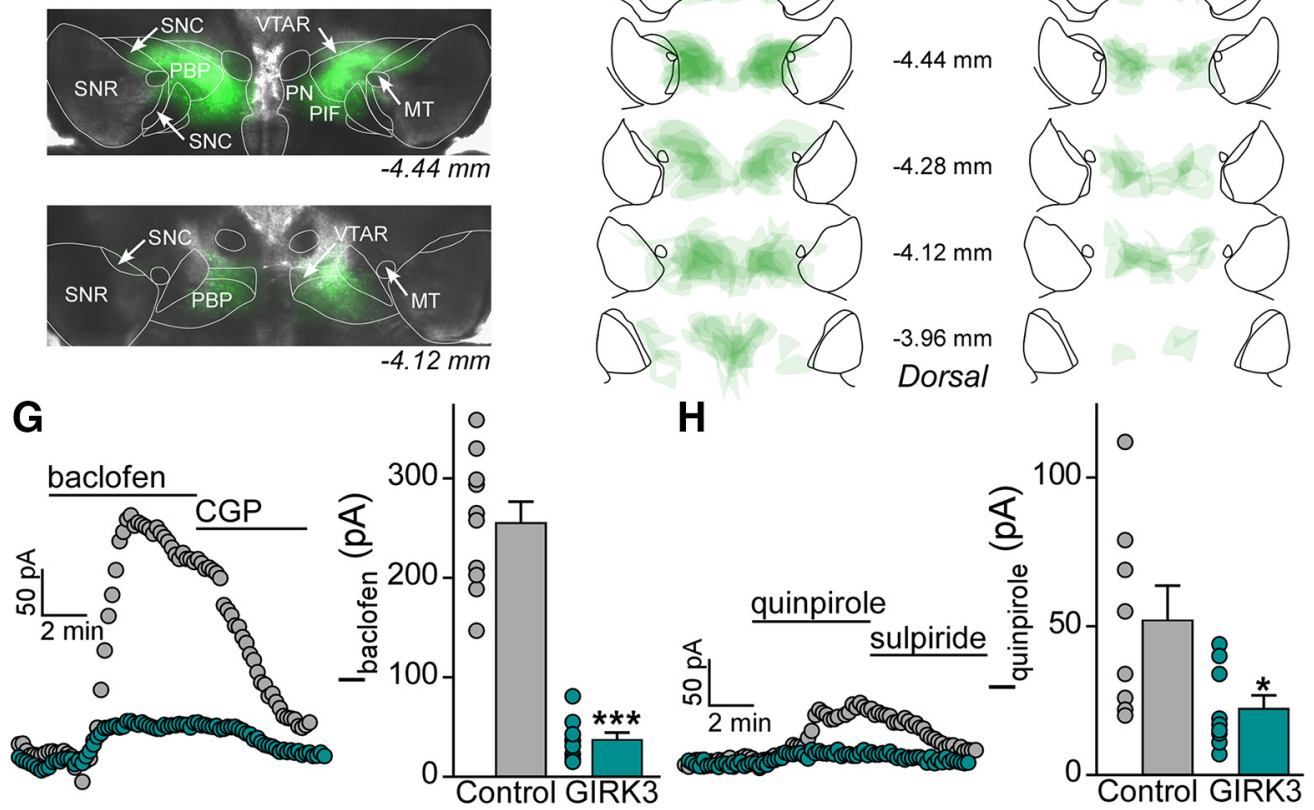

Figure 3. Viral suppression of GIRK channel activity in VTA DA neurons increases behavioral sensitivity to cocaine. A, DATCre(+) mice were injected with control or GIRK3 virus. Mice were tested for EPM, FST, and cocaine locomotor activity 3 weeks after surgery, with each task separated by at least $1 \mathrm{~d}$. Following behavior, mice were processed for placement and electrophysiology validation. $\boldsymbol{B}$, EPM percent time in open arms is not different in control mice $(n=17,33 \pm 5 \%)$ and GIRK3 mice $(n=14,30 \pm 3 \% ; t$ test, $t(29)=0.396, p=0.695)$. C, FST time immobile during the final 4 min of the task does not differ between control mice $(n=12,112 \pm 13 \mathrm{~s})$ and GIRK3 mice $(n=11,131 \pm 14 \mathrm{~s} ; t$ test, $t(21)=0.957, p=0.350)$. $D$, Distance moved on the handling habituation day was not different between control mice $(n=17,119 \pm 6 \mathrm{~m} / \mathrm{h})$ and GIRK3 $(n=15,126 \pm 9 \mathrm{~m} / \mathrm{h} ; t$ test, $t(30)=0.630, p=0.534)$. $\boldsymbol{E}$, Distanced traveled following injection of $0,3,15$, and $30 \mathrm{mg} / \mathrm{kg}$ cocaine resulted in interaction between cocaine dose and virus (two-way repeated-measures ANOVA, $F_{(3,90)}=3.438$, $p=0.020$; Bonferroni post hoc test at $15 \mathrm{mg} / \mathrm{kg}$ cocaine, $t=4.111, p<0.001) . \boldsymbol{F}$, Representative images of viral spread in horizontal slices from a mouse in the control condition, imaged at $2 \times$ just before electrophysiology, and summary of viral spread for all mice in control and GIRK3 conditions. MT, Medial terminal nucleus of the accessory optic tract; SNC, substantia nigra, compact part; SNCD, substantia nigra, compact part, dorsal tier; SNR, substantia nigra, reticular part; PBP, parabrachial pigmented nucleus of the VTA; PIF, parainterfascicular nucleus of the VTA; PN, paranigral nucleus of the VTA; VTAR, ventral tegmental area, rostral part. G, GABA RR-GIRK currents in the GIRK3 group $(n=9$ cells from 8 mice, $38 \pm 7$ pA) are significantly smaller than those in the control virus condition ( $n=10$ cells from 6 mice, $255 \pm 21 \mathrm{pA}$; Mann-Whitney $U$ test, $U=0.0, p<0.0001)$. $\boldsymbol{H}, \mathrm{D}_{2} \mathrm{R}-\mathrm{GIRK}$ currents in the GIRK3 group ( $n=9$ cells from 7 mice, $22 \pm 4 \mathrm{pA}$ ) are significantly smaller than those in the control virus condition ( $n=8$ cells from 6 mice, $52 \pm 12 \mathrm{pA}$; Mann-Whitney $U$ test, $U=11.50$, $p=0.021) .{ }^{*} p<0.05 .{ }^{* *} p<0.001$. 

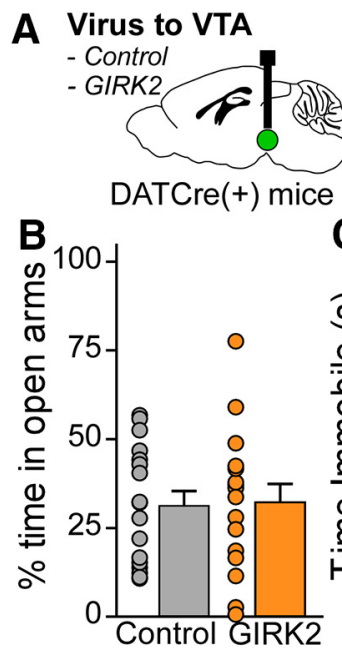

C

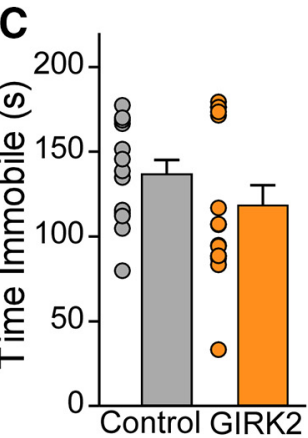

D

Behavior

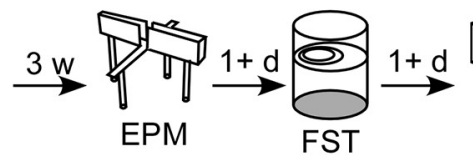

Electrophysiology

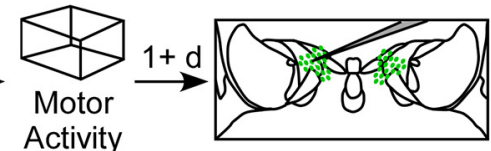

E

$\mathbf{F}$
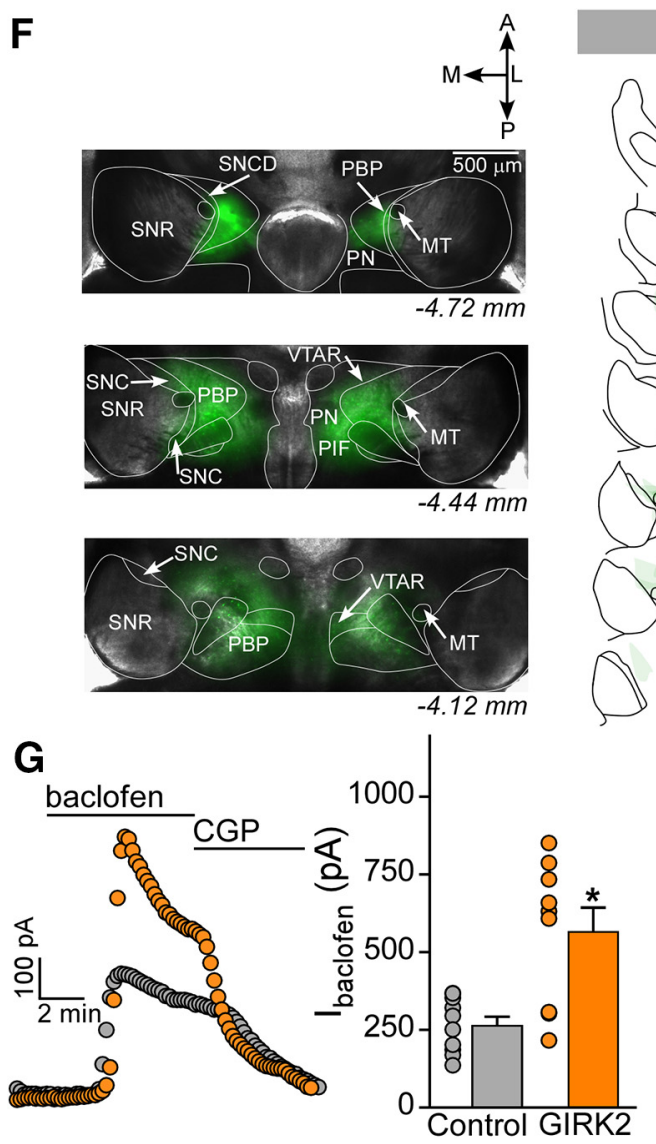

\section{Control}

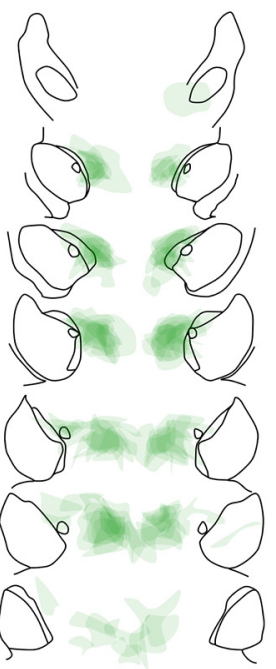

H

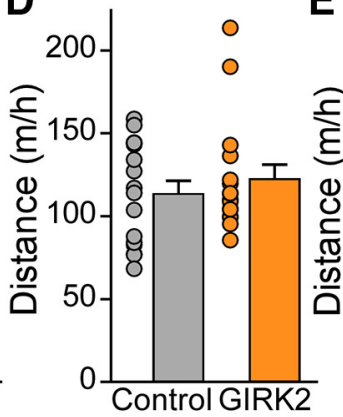

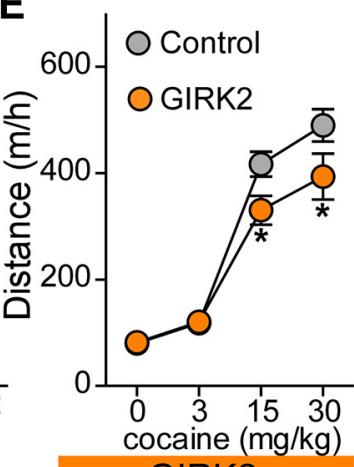

GIRK2

Ventral $-4.88 \mathrm{~mm}$

$-4.72 \mathrm{~mm}$

$-4.56 \mathrm{~mm}$

$-4.44 \mathrm{~mm}$

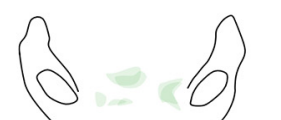

$-4.28 \mathrm{~mm}$
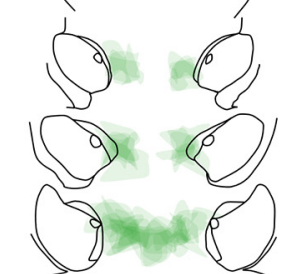<smiles>[C]1CCCC1</smiles>

$-4.12 \mathrm{~mm}$<smiles>CCCC1CCCCC1</smiles>

$-3.96 \mathrm{~mm}$

Dorsal
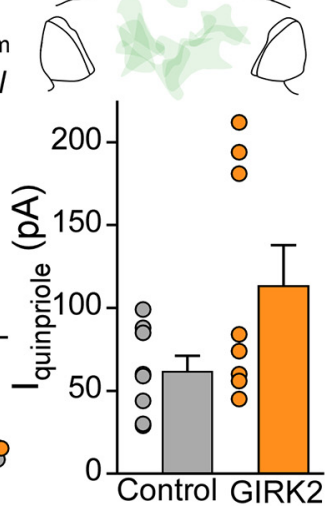

Figure 4. Viral enhancement of GIRK channel activity in VTA DA neurons decreases behavioral sensitivity to cocaine. $\boldsymbol{A}$, Schematic of experiment, in which DATCre $(+)$ mice were injected with control of GIRK2 virus. Three weeks following surgery, mice were tested for EPM, FST, and cocaine locomotor activity, with each task separated by at least $1 \mathrm{~d}$. Following behavior, mice were processed for placement and electrophysiology validation. $\boldsymbol{B}$, EPM percent time in open arms is not different in control mice $(n=17,31 \pm 4 \%)$ and GIRK 2 mice $(n=$ $16,32 \pm 5 \% ; t$ test, $\left.t_{(31)}=0.1446, p=0.8860\right)$. C, FST time immobile during the final 4 min of the task does not differ between control mice $(n=13,137 \pm 8 \mathrm{~s})$ and GIRK 2 mice $(n=$ $15,119 \pm 12 \mathrm{~s}$; Mann-Whitney $U$ test, $U=76, p=0.3334)$. D, Distance moved on the handling habituation day was not different between control mice $(n=16,114 \pm 8 \mathrm{~m} / \mathrm{h})$ and GIRK2 mice ( $n=16,123 \pm 9 \mathrm{~m} / \mathrm{h}$; Mann-Whitney $U$ test, $U=119, p=0.7487$ ). $\boldsymbol{E}$, Distanced traveled following injection of $0,3,15$, and $30 \mathrm{mg} / \mathrm{kg}$ cocaine resulted in interaction between cocaine dose and virus (two-way repeated-measures ANOVA, $F_{(3,90)}=3.054, p=0.032$; Bonferroni post hoc test for $15 \mathrm{mg} / \mathrm{kg}, t=2.548, p=0.012$, for $30 \mathrm{mg} / \mathrm{kg}, t=2.824$, $p=0.006) . F$, Representative images of viral spread in horizontal slices from a mouse in the control condition, imaged at $2 \times$ just before electrophysiology, and summary of viral spread for all mice in control and GIRK2 conditions. MT, Medial terminal nucleus of the accessory optic tract; SNC, substantia nigra, compact part; SNCD, substantia nigra, compact part, dorsal tier; SNR, substantia nigra, reticular part; PBP, parabrachial pigmented nucleus of the VTA; PIF, parainterfascicular nucleus of the VTA; PN, paranigral nucleus of the VTA; VTAR, ventral tegmental area, rostral part. G, GABA ${ }_{B}$ R-GIRK currents in the GIRK2 condition ( $n=9$ cells from 7 mice, $566 \pm 77 \mathrm{pA}$ ) are significantly higher than those in the control condition ( $n=10$ cells from 7 mice, $265 \pm 28 \mathrm{pA}$; Mann-Whitney $U$ test, $U=14, p=0.010)$. $\boldsymbol{H}, \mathrm{D}_{2} \mathrm{R}$-GIRK currents are not significantly different in control ( $n=8$ cells from 5 mice, $62 \pm 9 \mathrm{pA}$ ) and GIRK2 conditions ( $n=8$ cells from 7 mice, $113 \pm 25$ pA; Mann-Whitney $U$ test, $U=19.50, p=0.207$ ). ${ }^{*} p<0.05$. 
GIRK2c and GIRK3 to regulate channel trafficking, decreased $\mathrm{GABA}_{\mathrm{B}} \mathrm{R}$ - and $\mathrm{D}_{2} \mathrm{R}$-GIRK signaling and increased behavioral responding to cocaine (Lunn et al., 2007; Munoz and Slesinger, 2014; Rifkin et al., 2018). $\mathrm{D}_{2}$ Rs in DA neurons have also been implicated in modulating behavioral sensitivity to cocaine. Indeed, mice lacking $\mathrm{D}_{2} \mathrm{R}$ in DA neurons display increased cocaineinduced locomotor activity, increased preference for a low dose of cocaine in the conditioned place preference test, and accelerated acquisition of self-administration (Bello et al., 2011; Holroyd et al., 2015). The interpretation of these DA neuron-specific genetic manipulations is limited by their congenital nature and lack of regional selectivity, which makes it challenging to dissociate them from developmental alterations and to attribute behavioral phenotypes to a specific dopaminergic population. Here, we report that genetic enhancement or suppression of GIRKdependent signaling in adult mouse VTA DA neurons decreased or increased, respectively, behavioral sensitivity to cocaine.

The impact of VTA DA neuron GIRK channels on behavioral sensitivity to cocaine is likely attributable in large part to the engagement of $\mathrm{GABA}_{\mathrm{B}} \mathrm{R}$ - and/or $\mathrm{D}_{2} \mathrm{R}$-dependent signaling by cocaine. Indeed, increased synaptic DA levels evoked by cocaine activates both terminal and somatodendritic $\mathrm{D}_{2}$ Rs (Brodie and Dunwiddie, 1990; Beckstead et al., 2004). In addition, cocaine enhances GABAergic ("long-loop") feedback to VTA DA neurons by increasing DA in the NAc (Edwards et al., 2017). While VTA DA neurons receive GABAergic input from local interneurons and several regions (Morales and Margolis, 2017), NAcderived input from $\mathrm{D}_{1} \mathrm{R}$-expressing medium spiny neurons appears to selectively activate $\mathrm{GABA}_{\mathrm{B}}$ Rs in VTA DA neurons (Edwards et al., 2017; Yang et al., 2018). Notably, recent studies targeting $\mathrm{D}_{2} \mathrm{R}$ in VTA DA neurons have yielded outcomes of comparable magnitude as those reported herein following viral suppression of GIRK channel activity. For example, RNAidependent suppression of $\mathrm{D}_{2} \mathrm{R}$ in the rat VTA correlates with increased cocaine locomotor activity, as well as increased responding for cocaine and sucrose in a self-administration progressive ratio task (de Jong et al., 2015). Similarly, $G_{A B A} R$ ablation in VTA DA neurons correlated with increased cocaineinduced locomotor activity in mice (Edwards et al., 2017). It is important to note, however, that GIRK channels may mediate the effects of other inhibitory $G$ protein-coupled receptors on VTA DA neurons, such as $\kappa$ opioid and nociceptin receptors (Di Giannuario and Pieretti, 2000; Lutfy et al., 2001; Margolis et al., 2003; Ford et al., 2006). As such, the behavioral impact of VTA DA neuron-specific manipulations on GIRK channel activity may reflect in part the modulation of signaling via these receptors as well.

\section{Suppression of VTA DA neuron GIRK channel activity by GIRK3}

Similar to other published results (Kofuji et al., 1995; Lesage et al., 1995; Ma et al., 2002), we found that overexpression of GIRK3 neurons yielded a robust suppression of GIRK channel activity in VTA DA neurons. The molecular mechanisms underlying this dominant negative influence of ectopic GIRK3 are unclear. Overexpression of GIRK3 may enhance trafficking of GIRK channels to internal sites, a prospect supported by the presence of a lysosomal targeting motif in the GIRK3 carboxyl-terminal domain (Ma et al., 2002). GIRK3 might promote an interaction between the VTA DA neuron GIRK channel and SNX27, which can bidirectionally regulate channel trafficking (Lunn et al., 2007; Munoz and Slesinger, 2014). The presence of GIRK3 could also increase the negative regulatory influence of regulator of $G$ protein signal- ing 2 (RGS2) on GIRK-dependent signaling in VTA DA neurons (Jelacic et al., 2000; Labouèbe et al., 2007). Interestingly, activitydependent and pyschostimulant-induced plasticity of GIRK channel activity in VTA DA neurons is dependent upon GIRK3 (Lalive et al., 2014; Munoz et al., 2016). Given these observations, it is tempting to speculate that GIRK3 titrates the strength of GIRK channel activity in VTA DA neurons via the extent to which it incorporates into the GIRK2/GIRK3 heterotetromeric channel.

\section{GIRK channels and negative affective behavior}

Girk $2^{-1-}$ mice display reduced anxiety- and depression-related behaviors, which are modulated by DA (Pravetoni and Wickman, 2008; Llamosas et al., 2015; Zarrindast and Khakpai, 2015; Belujon and Grace, 2017). While viral manipulation of GIRK channel activity in VTA DA neurons did not alter these behaviors, male DATCre(+):Girk $f^{f l f l}$ mice displayed decreased depressionrelated behavior, congruent with findings from another DATCre: Girk $2^{f l / f l}$ line (Honda et al., 2018). The apparent discrepancy in depression-related behavior in DATCre $(+)$ :Girk2 $2^{f l f l}$ mice and the viral loss-of-function model could reflect a lack of penetrance in the viral manipulation, developmental compensation in DAT$\mathrm{Cre}(+)$ :Girk $2^{f l / f l}$ mice, or the influence of a different, non-VTA population of DA neurons on this behavior.

The lack of anxiolytic phenotype in DATCre $(+)$ :Girk $2^{f l f l}$ and viral gain- and loss-of-function models suggests that GIRKdependent signaling in VTA DA neurons does not contribute to baseline anxiety-related behavior. The anxiolytic phenotype observed in both Girk1 $1^{-1-}$ and Girk2 $2^{-1-}$ mice, and the anxiolytic efficacy of a direct-acting agonist of GIRK1-containing channels (ML297), support the contention that neuron populations expressing GIRK1-containing channels impact baseline anxiety in mice, not the GIRK1-lacking midbrain DA neurons (Cruz et al., 2004; Pravetoni and Wickman, 2008; Wydeven et al., 2014).

Overall, the outcomes of our viral manipulations suggest that GIRK-dependent signaling in VTA DA neurons exerts a minimal influence on negative affective behavior at baseline. However, the prior experience of subjects in our study is meaningfully distinct from that of mice in studies in which VTA DA neuron excitability was shown to correlate with altered negative affective behavior. Indeed, mice subjected to social defeat stress that subsequently displayed depressive-like behavior ("susceptible" mice) also displayed increased VTA DA neuron excitability (Cao et al., 2010; Chaudhury et al., 2013; Friedman et al., 2014, 2016). In this context, it is noteworthy that, while our viral manipulations did alter the amplitude of GIRK-dependent somatodendritic currents in VTA DA neurons, they exerted little or no impact on the excitability of VTA DA neurons (Table 1).

\section{Future directions}

A rich body of recent work has demonstrated that separate dopaminergic projections emanating from the VTA participate in distinct behaviors (Lammel et al., 2014; Holly and Miczek, 2016; Juarez and Han, 2016; Morales and Margolis, 2017). For example, DA neurons in the lateral VTA, which project to the lateral NAc shell, are responsive to rewarding stimuli (Lammel et al., 2011, 2012). In contrast, more medial VTA DA neurons projecting to the PFC and the core and medial shell of the NAc have been implicated in responding to aversive stimuli (Lammel et al., 2008, 2012; Vander Weele et al., 2018; de Jong et al., 2019). Interestingly, although overexpression of GIRK2 enhanced $\mathrm{GABA}_{\mathrm{B}} \mathrm{R}$ GIRK signaling in VTA DA neurons, we did not observe a significant increase in $\mathrm{D}_{2} \mathrm{R}$-GIRK signaling with this manipulation (Fig. 4H). Rather, there appeared to be two distinct popu- 
lations of VTA DA neurons in our study: one with unaltered $\mathrm{D}_{2} \mathrm{R}$-GIRK responses and one with enhanced responses. It is possible that $\mathrm{D}_{2} \mathrm{Rs}$ and GIRK channels are maximally coupled in the former population (e.g., $D_{2} R$ level is the factor limiting $D_{2} R$ GIRK signaling strength), which renders overexpression of GIRK2 functionally inert. In the latter population, the GIRK channel level may limit the strength of $\mathrm{D}_{2} \mathrm{R}$-GIRK signaling at baseline. It is possible that this diversity of $\mathrm{D}_{2} \mathrm{R}-\mathrm{GIRK}$ signaling aligns with distinct, projection-defined subpopulations of VTA DA neurons (Lammel et al., 2008). Further investigation will be needed to determine whether GIRK-dependent signaling in discrete VTA DA neuron projections mediates behavioral sensitivity to cocaine, and whether selective strengthening of GIRK channel activity in these projections might suppress other cocaine-related behaviors, including acquisition of self-administration or reinstatement.

\section{References}

Anstrom KK, Woodward DJ (2005) Restraint increases dopaminergic burst firing in awake rats. Neuropsychopharmacology 30:1832-1840.

Aragona BJ, Cleaveland NA, Stuber GD, Day JJ, Carelli RM, Wightman RM (2008) Preferential enhancement of dopamine transmission within the nucleus accumbens shell by cocaine is attributable to a direct increase in phasic dopamine release events. J Neurosci 28:8821-8831.

Arora D, Haluk DM, Kourrich S, Pravetoni M, Fernández-Alacid L, Nicolau JC, Luján R, Wickman K (2010) Altered neurotransmission in the mesolimbic reward system of Girk mice. J Neurochem 114:1487-1497.

Arora D, Hearing M, Haluk DM, Mirkovic K, Fajardo-Serrano A, Wessendorf MW, Watanabe M, Luján R, Wickman K (2011) Acute cocaine exposure weakens $\mathrm{GABA}(\mathrm{B})$ receptor-dependent G-protein-gated inwardly rectifying $\mathrm{K}^{+}$signaling in dopamine neurons of the ventral tegmental area. J Neurosci 31:12251-12257.

Bäckman CM, Malik N, Zhang Y, Shan L, Grinberg A, Hoffer BJ, Westphal H, Tomac AC (2006) Characterization of a mouse strain expressing Cre recombinase from the $3^{\prime}$ untranslated region of the dopamine transporter locus. Genesis 44:383-390.

Beckstead MJ, Grandy DK, Wickman K, Williams JT (2004) Vesicular dopamine release elicits an inhibitory postsynaptic current in midbrain dopamine neurons. Neuron 42:939-946.

Bello EP, Mateo Y, Gelman DM, Noaín D, Shin JH, Low MJ, Alvarez VA, Lovinger DM, Rubinstein M (2011) Cocaine supersensitivity and enhanced motivation for reward in mice lacking dopamine D2 autoreceptors. Nat Neurosci 14:1033-1038.

Belujon P, Grace AA (2017) Dopamine system dysregulation in major depressive disorders. Int J Neuropsychopharmacol 20:1036-1046.

Blednov YA, Stoffel M, Chang SR, Harris RA (2001) Potassium channels as targets for ethanol: studies of G-protein-coupled inwardly rectifying potassium channel 2 (GIRK2) null mutant mice. J Pharmacol Exp Ther 298:521-530.

Blednov YA, Stoffel M, Alva H, Harris RA (2003) A pervasive mechanism for analgesia: activation of GIRK2 channels. Proc Natl Acad Sci U S A 100:277-282.

Brodie MS, Dunwiddie TV (1990) Cocaine effects in the ventral tegmental area: evidence for an indirect dopaminergic mechanism of action. Naunyn Schmiedebergs Arch Pharmacol 342:660-665.

Cao JL, Covington HE 3rd, Friedman AK, Wilkinson MB, Walsh JJ, Cooper DC, Nestler EJ, Han MH (2010) Mesolimbic dopamine neurons in the brain reward circuit mediate susceptibility to social defeat and antidepressant action. J Neurosci 30:16453-16458.

Chaudhury D, Walsh JJ, Friedman AK, Juarez B, Ku SM, Koo JW, Ferguson D, Tsai HC, Pomeranz L, Christoffel DJ, Nectow AR, Ekstrand M, Domingos A, Mazei-Robison MS, Mouzon E, Lobo MK, Neve RL, Friedman JM, Russo SJ, Deisseroth K, et al. (2013) Rapid regulation of depressionrelated behaviours by control of midbrain dopamine neurons. Nature 493:532-536.

Costa AC, Stasko MR, Stoffel M, Scott-McKean JJ (2005) G-protein-gated potassium (GIRK) channels containing the GIRK2 subunit are control hubs for pharmacologically induced hypothermic responses. J Neurosci 25:7801-7804.

Cruz HG, Ivanova T, Lunn ML, Stoffel M, Slesinger PA, Lüscher C (2004)
Bi-directional effects of GABA(B) receptor agonists on the mesolimbic dopamine system. Nat Neurosci 7:153-159.

de Jong JW, Roelofs TJ, Mol FM, Hillen AE, Meijboom KE, Luijendijk MC, van der Eerden HA, Garner KM, Vanderschuren LJ, Adan RA (2015) Reducing ventral tegmental dopamine D2 receptor expression selectively boosts incentive motivation. Neuropsychopharmacology 40:2085-2095.

de Jong JW, Afjei SA, Pollak Dorocic I, Peck JR, Liu C, Kim CK, Tian L, Deisseroth K, Lammel S (2019) A neural circuit mechanism for encoding aversive stimuli in the mesolimbic dopamine system. Neuron 101:133-151.e7.

Demaria JE, Nagy GM, Lerant AA, Fekete MI, Levenson CW, Freeman ME (2000) Dopamine transporters participate in the physiological regulation of prolactin. Endocrinology 141:366-374.

Di Chiara G, Imperato A (1988) Drugs abused by humans preferentially increase synaptic dopamine concentrations in the mesolimbic system of freely moving rats. Proc Natl Acad Sci U S A 85:5274-5278.

Di Giannuario A, Pieretti S (2000) Nociceptin differentially affects morphine-induced dopamine release from the nucleus accumbens and nucleus caudate in rats. Peptides 21:1125-1130.

Edwards NJ, Tejeda HA, Pignatelli M, Zhang S, McDevitt RA, Wu J, Bass CE, Bettler B, Morales M, Bonci A (2017) Circuit specificity in the inhibitory architecture of the VTA regulates cocaine-induced behavior. Nat Neurosci $20: 438-448$

Ford CP (2014) The role of D2-autoreceptors in regulating dopamine neuron activity and transmission. Neuroscience 282:13-22.

Ford CP, Mark GP, Williams JT (2006) Properties and opioid inhibition of mesolimbic dopamine neurons vary according to target location. J Neurosci 26:2788-2797.

Franklin KB, Paxinos G (2008) The mouse brain in stereotaxic coordinates, Ed 3. San Diego: Academic

Friedman AK, Walsh JJ, Juarez B, Ku SM, Chaudhury D, Wang J, Li X, Dietz DM, Pan N, Vialou VF, Neve RL, Yue Z, Han MH (2014) Enhancing depression mechanisms in midbrain dopamine neurons achieves homeostatic resilience. Science 344:313-319.

Friedman AK, Juarez B, Ku SM, Zhang H, Calizo RC, Walsh JJ, Chaudhury D, Zhang S, Hawkins A, Dietz DM, Murrough JW, Ribadeneira M, Wong EH, Neve RL, Han MH (2016) KCNQ channel openers reverse depressive symptoms via an active resilience mechanism. Nat Commun 7:11671.

Hall F, Sora I, Drgonova J, Li X, Goeb M, Uhl G (2004) Molecular mechanisms underlying the rewarding effects of cocaine. Ann N Y Acad Sci 1025:47-56.

Hearing MC, Zink AN, Wickman K (2012) Cocaine-induced adaptations in metabotropic inhibitory signaling in the mesocorticolimbic system. Rev Neurosci 23:325-351.

Hearing M, Kotecki L, Marron Fernandez de Velasco E, Fajardo-Serrano A, Chung HJ, Luján R, Wickman K (2013) Repeated cocaine weakens GABAB-GIRK signaling in layer $5 / 6$ pyramidal neurons in the prelimbic cortex. Neuron 80:159-170.

Holly EN, Miczek KA (2016) Ventral tegmental area dopamine revisited: effects of acute and repeated stress. Psychopharmacology (Berl) 233:163186.

Holroyd KB, Adrover MF, Fuino RL, Bock R, Kaplan AR, Gremel CM, Rubinstein M, Alvarez VA (2015) Loss of feedback inhibition via D2 autoreceptors enhances acquisition of cocaine taking and reactivity to drugpaired cues. Neuropsychopharmacology 40:1495-1509.

Honda I, Araki K, Honda S, Soeda F, Shin MC, Misumi S, Yamamura KI, Takahama K (2018) Deletion of GIRK2 subunit containing GIRK channels of neurons expressing dopamine transporter decrease immobility time on forced swimming in mice. Neurosci Lett 665:140-146.

Jelacic TM, Kennedy ME, Wickman K, Clapham DE (2000) Functional and biochemical evidence for G-protein-gated inwardly rectifying $\mathrm{K}^{+}$ (GIRK) channels composed of GIRK2 and GIRK3. J Biol Chem 275: 36211-36216

Juarez B, Han MH (2016) Diversity of dopaminergic neural circuits in response to drug exposure. Neuropsychopharmacology 41:2424-2446.

Kofuji P, Davidson N, Lester HA (1995) Evidence that neuronal G-proteingated inwardly rectifying $\mathrm{K}^{+}$channels are activated by $\mathrm{G}$ beta gamma subunits and function as heteromultimers. Proc Natl Acad Sci U S A 92: 6542-6546.

Kotecki L, Hearing M, McCall NM, Marron Fernandez de Velasco E, Pravetoni M, Arora D, Victoria NC, Munoz MB, Xia Z, Slesinger PA, Weaver CD, Wickman K (2015) GIRK channels modulate opioid-induced mo- 
tor activity in a cell type- and subunit-dependent manner. J Neurosci 35:7131-7142.

Krishnan V, Han MH, Graham DL, Berton O, Renthal W, Russo SJ, Laplant Q, Graham A, Lutter M, Lagace DC, Ghose S, Reister R, Tannous P, Green TA, Neve RL, Chakravarty S, Kumar A, Eisch AJ, Self DW, Lee FS, et al. (2007) Molecular adaptations underlying susceptibility and resistance to social defeat in brain reward regions. Cell 131:391-404.

Labouèbe G, Lomazzi M, Cruz HG, Creton C, Luján R, Li M, Yanagawa Y, Obata K, Watanabe M, Wickman K, Boyer SB, Slesinger PA, Lüscher C (2007) RGS2 modulates coupling between GABAB receptors and GIRK channels in dopamine neurons of the ventral tegmental area. Nat Neurosci 10:1559-1568.

Lalive AL, Munoz MB, Bellone C, Slesinger PA, Lüscher C, Tan KR (2014) Firing modes of dopamine neurons drive bidirectional GIRK channel plasticity. J Neurosci 34:5107-5114.

Lammel S, Hetzel A, Häckel O, Jones I, Liss B, Roeper J (2008) Unique properties of mesoprefrontal neurons within a dual mesocorticolimbic dopamine system. Neuron 57:760-773.

Lammel S, Ion DI, Roeper J, Malenka RC (2011) Projection-specific modulation of dopamine neuron synapses by aversive and rewarding stimuli. Neuron 70:855-862.

Lammel S, Lim BK, Ran C, Huang KW, Betley MJ, Tye KM, Deisseroth K, Malenka RC (2012) Input-specific control of reward and aversion in the ventral tegmental area. Nature 491:212-217.

Lammel S, Lim BK, Malenka RC (2014) Reward and aversion in a heterogeneous midbrain dopamine system. Neuropharmacology 76:351-359.

Lammel S, Steinberg EE, Földy C, Wall NR, Beier K, Luo L, Malenka RC (2015) Diversity of transgenic mouse models for selective targeting of midbrain dopamine neurons. Neuron 85:429-438.

Lesage F, Guillemare E, Fink M, Duprat F, Heurteaux C, Fosset M, Romey G, Barhanin J, Lazdunski M (1995) Molecular properties of neuronal G-protein-activated inwardly rectifying $\mathrm{K}^{+}$channels. J Biol Chem 270:28660-28667.

Llamosas N, Bruzos-Cidón C, Rodríguez JJ, Ugedo L, Torrecilla M (2015) Deletion of GIRK2 subunit of GIRK channels alters the 5-HT 1A receptor-mediated signaling and results in a depression-resistant behavior. Int J Neuropsychopharmacol 18:pyv051.

Lorang D, Amara SG, Simerly RB (1994) Cell-type-specific expression of catecholamine transporters in the rat brain. J Neurosci 14:4903-4914.

Luján R, Marron Fernandez de Velasco E, Aguado C, Wickman K (2014) New insights into the therapeutic potential of Girk channels. Trends Neurosci 37:20-29.

Lunn ML, Nassirpour R, Arrabit C, Tan J, McLeod I, Arias CM, Sawchenko PE, Yates JR 3rd, Slesinger PA (2007) A unique sorting nexin regulates trafficking of potassium channels via a PDZ domain interaction. Nat Neurosci 10:1249-1259.

Lutfy K, Do T, Maidment NT (2001) Orphanin FQ/nociceptin attenuates motor stimulation and changes in nucleus accumbens extracellular dopamine induced by cocaine in rats. Psychopharmacology (Berl) 154:1-7.

Ma D, Zerangue N, Raab-Graham K, Fried SR, Jan YN, Jan LY (2002) Diverse trafficking patterns due to multiple traffic motifs in $\mathrm{G}$ proteinactivated inwardly rectifying potassium channels from brain and heart. Neuron 33:715-729.

Margolis EB, Hjelmstad GO, Bonci A, Fields HL (2003) Kappa-opioid agonists directly inhibit midbrain dopaminergic neurons. J Neurosci 23: 9981-9986.

Marker CL, Stoffel M, Wickman K (2004) Spinal G-protein-pated K ${ }^{+}$channels formed by GIRK1 and GIRK2 subunits modulate thermal nociception and contribute to morphine analgesia. J Neurosci 24:2806-2812.

Marker CL, Luján R, Loh HH, Wickman K (2005) Spinal G-protein-gated potassium channels contribute in a dose-dependent manner to the analgesic effect of mu- and delta- but not kappa-opioids. J Neurosci 25:35513559.

Marron Fernandez de Velasco E, McCall N, Wickman K (2015) GIRK channel plasticity and implications for drug addiction. Int Rev Neurobiol 123:201-238.
McCall NM, Kotecki L, Dominguez-Lopez S, Marron Fernandez de Velasco E, Carlblom N, Sharpe AL, Beckstead MJ, Wickman K (2017) Selective ablation of GIRK channels in dopamine neurons alters behavioral effects of cocaine in mice. Neuropsychopharmacology 42:707-715.

Meister B, Elde R (1993) Dopamine transporter mRNA in neurons of the rat hypothalamus. Neuroendocrinology 58:388-395.

Morales M, Margolis EB (2017) Ventral tegmental area: cellular heterogeneity, connectivity and behaviour. Nat Rev Neurosci 18:73-85.

Morgan AD, Carroll ME, Loth AK, Stoffel M, Wickman K (2003) Decreased cocaine self-administration in Kir3 potassium channel subunit knockout mice. Neuropsychopharmacology 28:932-938.

Munoz MB, Slesinger PA (2014) Sorting nexin 27 regulation of G proteingated inwardly rectifying $\mathrm{K}^{+}$channels attenuates in vivo cocaine response. Neuron 82:659-669.

Munoz MB, Padgett CL, Rifkin R, Terunuma M, Wickman K, Contet C, Moss SJ, Slesinger PA (2016) A role for the GIRK3 subunit in methamphetamine-induced attenuation of GABAB receptor-activated GIRK currents in VTA dopamine neurons. J Neurosci 36:3106-3114.

Nestler EJ, Carlezon WA Jr (2006) The mesolimbic dopamine reward circuit in depression. Biol Psychiatry 59:1151-1159.

Polter AM, Kauer JA (2014) Stress and VTA synapses: implications for addiction and depression. Eur J Neurosci 39:1179-1188.

Pravetoni M, Wickman K (2008) Behavioral characterization of mice lacking GIRK/Kir3 channel subunits. Genes Brain Behav 7:523-531.

Rifkin RA, Moss SJ, Slesinger PA (2017) G protein-gated potassium channels: a link to drug addiction. Trends Pharmacol Sci 38:378-392.

Rifkin RA, Huyghe D, Li X, Parakala M, Aisenberg E, Moss SJ, Slesinger PA (2018) GIRK currents in VTA dopamine neurons control the sensitivity of mice to cocaine-induced locomotor sensitization. Proc Natl Acad Sci U S A 115:E9479-E9488.

Rocha BA (2003) Stimulant and reinforcing effects of cocaine in monoamine transporter knockout mice. Eur J Pharmacol 479:107-115.

Russo SJ, Nestler EJ (2013) The brain reward circuitry in mood disorders. Nat Rev Neurosci 14:609-625.

Signorini S, Liao YJ, Duncan SA, Jan LY, Stoffel M (1997) Normal cerebellar development but susceptibility to seizures in mice lacking $G$ proteincoupled, inwardly rectifying $\mathrm{K}^{+}$channel GIRK2. Proc Natl Acad Sci U S A 94:923-927.

Steketee JD, Kalivas PW (1991) Sensitization to psychostimulants and stress after injection of pertussis toxin into the A10 dopamine region. J Pharmacol Exp Ther 259:916-924.

Stuber GD, Stamatakis AM, Kantak PA (2015) Considerations when using Cre-driver rodent lines for studying ventral tegmental area circuitry. Neuron 85:439-445.

Tye KM, Mirzabekov JJ, Warden MR, Ferenczi EA, Tsai HC, Finkelstein J, Kim SY, Adhikari A, Thompson KR, Andalman AS, Gunaydin LA, Witten IB, Deisseroth K (2013) Dopamine neurons modulate neural encoding and expression of depression-related behaviour. Nature 493:537-541.

Vander Weele CM, Siciliano CA, Matthews GA, Namburi P, Izadmehr EM, Espinel IC, Nieh EH, Schut EH, Padilla-Coreano N, Burgos-Robles A, Chang CJ, Kimchi EY, Beyeler A, Wichmann R, Wildes CP, Tye KM (2018) Dopamine enhances signal-to-noise ratio in cortical-brainstem encoding of aversive stimuli. Nature 563:397-401.

Volkow ND, Wang GJ, Fowler JS, Tomasi D (2012) Addiction circuitry in the human brain. Annu Rev Pharmacol Toxicol 52:321-336.

Wydeven N, Marron Fernandez de Velasco E, Du Y, Benneyworth MA, Hearing MC, Fischer RA, Thomas MJ, Weaver CD, Wickman K (2014) Mechanisms underlying the activation of G-protein-gated inwardly rectifying $\mathrm{K}^{+}$(GIRK) channels by the novel anxiolytic drug, ML297. Proc Natl Acad Sci U S A 111:10755-10760.

Yang H, de Jong JW, Tak Y, Peck J, Bateup HS, Lammel S (2018) Nucleus accumbens subnuclei regulate motivated behavior via direct inhibition and disinhibition of VTA dopamine subpopulations. Neuron 97:434449.e4.

Zarrindast MR, Khakpai F (2015) The modulatory role of dopamine in anxiety-like behavior. Arch Iran Med 18:591-603. 